- ....ny Corps

of Engineers

Waterways Experiment

Station
US-CE-C propepty of the

UNITED STATES GOVERINMENT

\title{
Ofu Harbor, American Samoa, Breakwater 2-D Hydraulic Stability Test
}

\author{
by George F. Turk
}

Approved For Public Release; Distribution is Unlimited

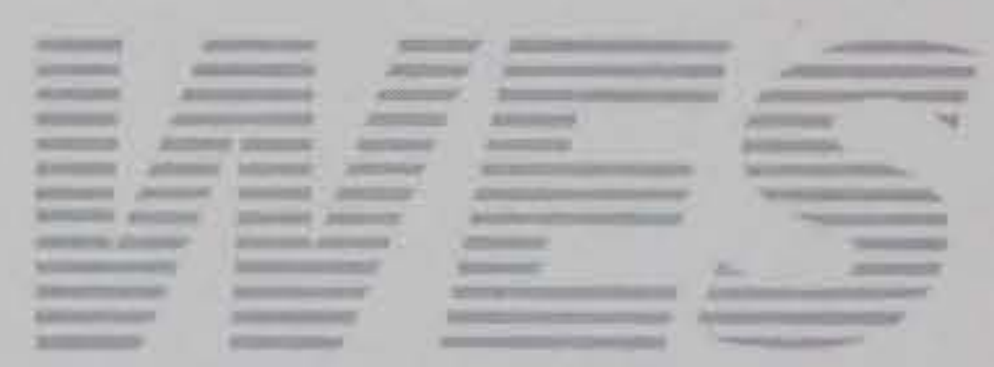

\author{
RESEARCH LIBRARY \\ US ARMY ENGINEER WATERWAYS \\ EXPERIMENT STATION \\ VICKSBURG, MISSISSIPPI
}

Prepared for U.S. Army Engineer Division, Pacific Ocean 
The contents of this report are not to be used for advertising, publication, or promotional purposes. Citation of trade names does not constitute an official endorsement or approval of the use
of such commercial products. 


\section{Ofu Harbor, American Samoa, Breakwater 2-D Hydraulic Stability Test c.3}

by George F. Turk

U.S. Army Corps of Engineers

Waterways Experiment Station

3909 Halls Ferry Road

Vicksburg, MS 39180-6199

Final report

Approved for public release; distribution is unlimited 


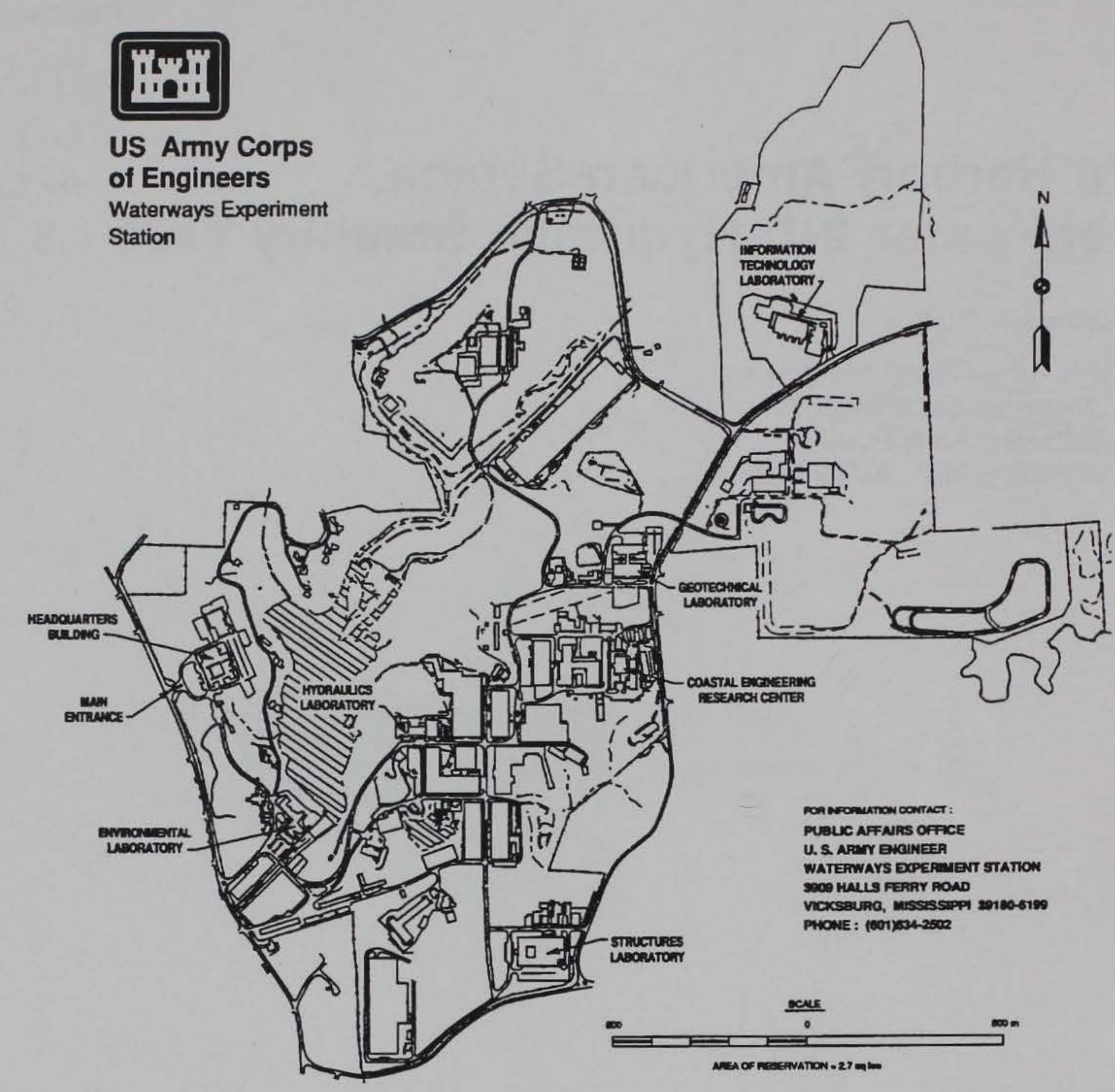

Waterways Experiment Station Cataloging-in-Publication Data

Turk, George F.

Ofu Harbor, American Samoa, breakwater 2-D hydraulic stability test /. by George F. Turk ; prepared for U.S. Army Engineer Division, Pacific Ocean.

36 p. : ill. ; $28 \mathrm{~cm}$. - (Technical report ; CERC-95-16)

Includes bibliographic references.

1. Breakwaters - American Samoa - Ofu Harbor. 2. Harbors American Samoa - Ofu. I. United States. Army. Corps of Engineers. Pacific Ocean Division. II. U.S. Army Engineer Waterways Experiment Station. III. Coastal Engineering Research Center (U.S. Army Engineer Waterways Experiment Station) IV. Title. V. Series: Technical report (U.S. Army Engineer Waterways Experiment Station) ; CERC-95-16.

TA7 W34 no.CERC-95-16 


\section{Contents}

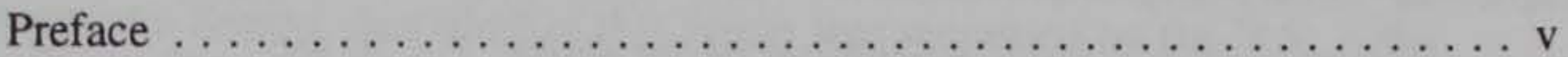

1-Introduction $\ldots \ldots \ldots \ldots \ldots \ldots \ldots \ldots \ldots \ldots \ldots \ldots \ldots \ldots \ldots$

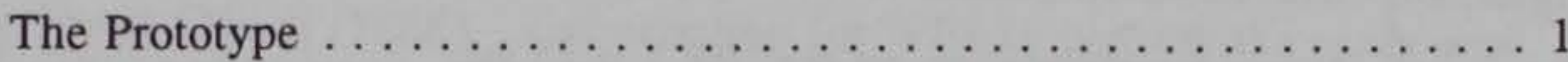

The Problem ........................ 1

Purpose of Study $\ldots \ldots \ldots \ldots \ldots \ldots \ldots \ldots \ldots \ldots \ldots \ldots \ldots \ldots \ldots \ldots \ldots$

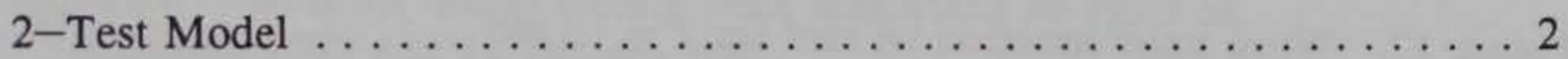

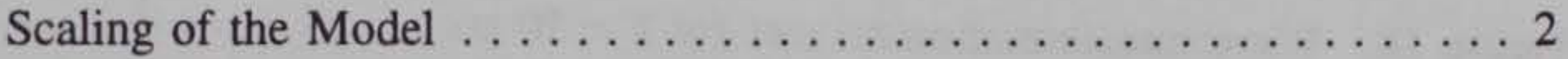

Test Facilities and Equipment $\ldots \ldots \ldots \ldots \ldots \ldots \ldots \ldots \ldots \ldots$

Breakwater Test Section . . . . . . . . . . . . . . . 4

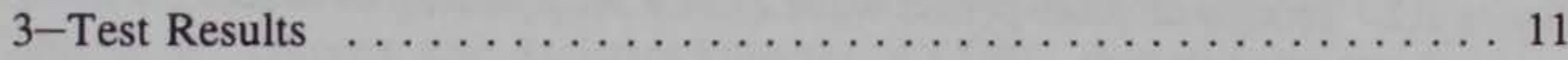

Data Acquisition . ...................... 11

Calibration/Test Conditions/Wave Height

Determination .............................. 11

Test Procedures ........................... 19

Reporting Model Observations $\ldots \ldots \ldots \ldots \ldots \ldots \ldots \ldots \ldots$

Summary of Two-Dimensional Stability Tests $\ldots \ldots \ldots \ldots \ldots \ldots 21$

4-Conclusions and Comments $\ldots \ldots \ldots \ldots \ldots \ldots \ldots \ldots \ldots . \ldots \ldots 22$

References ........................... 24

Appendix A: Photographs of Ofu Breakwater 2-D Stability

Tests

SF298

\section{List of Figures}

Figure 1. Flume layout $\ldots \ldots \ldots \ldots \ldots \ldots \ldots \ldots \ldots \ldots \ldots \ldots \ldots \ldots \ldots \ldots$

Figure 2. Breakwater configuration $\ldots \ldots \ldots \ldots \ldots \ldots \ldots \ldots$

Figure 3. Ofu breakwater alignment between Sta. $4+00$ and Sta. $6+72 \ldots 7$ 
Figure 4. 4.1 -tonne tribar $\ldots \ldots \ldots \ldots \ldots \ldots \ldots \ldots \ldots \ldots$

Figure 5. Thirty-percent porosity block used for underlayer . . . . . . 9

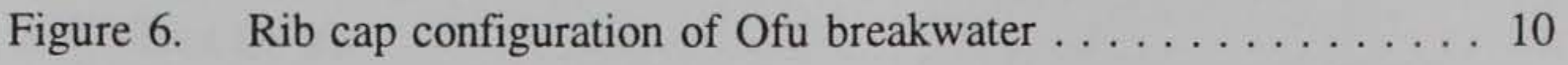

Figure 7. Wave heights as a function of board stroke, $T=9 \mathrm{sec} \ldots \ldots 12$

Figure 8. Wave heights as a function of board stroke, $T=11 \mathrm{sec} \ldots \ldots 13$

Figure 9. Wave heights as a function of board stroke, $T=13 \mathrm{sec} \ldots \ldots 13$

Figure 10. Wave heights as a function of board stroke, $T=15 \mathrm{sec} \ldots \ldots 14$

Figure 11. Wave heights as a function of board stroke, $T=17 \mathrm{sec} \ldots \ldots 14$

Figure 12. Wave heights as a function of board stroke, $T=18 \mathrm{sec} \ldots 15$

Figure 13. Wave heights as a function of board stroke, $T=20 \mathrm{sec} \ldots 15$

Figure 14. Maximum attainable wave height on reef at structure toe $\ldots 17$

Figure 15. Wave transformation on reef for $T=15 \mathrm{sec} \ldots \ldots \ldots \ldots 17$

Figure 16. Wave transformation on reef for $T=17 \mathrm{sec} \ldots \ldots \ldots \ldots 18$

Figure 17. Wave transformation on reef for $T=18 \mathrm{sec} \ldots \ldots \ldots \ldots 18$

Figure 18. Wave transformation on reef for $T=20 \mathrm{sec} \ldots \ldots \ldots \ldots$

Figure A1. Model of Ofu breakwater $\ldots \ldots \ldots \ldots \ldots \ldots \ldots \ldots \ldots \ldots \ldots \ldots \ldots$

Figure A2. Trough of short-period wave $(T=9 \mathrm{sec})$ passing over reef $\ldots$ A2

Figure A3. Short-period wave $(T=11 \mathrm{sec})$ breaking on reef $\ldots \ldots \ldots$ A3

Figure A4. Wave $(T=17 \mathrm{sec})$ breaking on structure $\ldots \ldots \ldots \ldots \ldots$ A3

Figure A5. Wave $(T=18 \mathrm{sec})$ breaking on structure $\ldots \ldots \ldots \ldots \ldots$ A4

\section{List of Tables}

Table 1. Model-Prototype Scale Relations (1:23 scale) $\ldots \ldots \ldots \ldots 2$

Table 2. Prototype and Model Material Sizes $\ldots \ldots \ldots \ldots \ldots \ldots$

Table 3. Stability Test Wave Conditions $\ldots \ldots \ldots \ldots \ldots \ldots \ldots$

Table 4. Summary of 2-D Stability Tests for 4.1-tonne Tribars . . . . . 21 


\section{Preface}

The two-dimensional physical model investigation of the Ofu breakwater, American Samoa, described in this report was requested by the U.S. Army Engineer Division, Pacific Ocean (POD) and conducted at the Coastal Engineering Research Center (CERC) of the U.S. Army Engineer Waterways Experiment Station (WES). Authorization for WES to perform the study was granted by POD in Intra-Army Order E9640008 dated 28 December 1993, which was subsequently approved by Headquarters, U.S. Army Corps of Engineers. Funds for model testing were authorized by POD on 27 December 1993 and 24 January 1994.

Model tests were conducted at WES during January 1994 by personnel of the Wave Research Branch (WRB) of the Wave Dynamics Division (WDD), CERC, under the direction of Dr. James R. Houston and Mr. Charles C. Calhoun, Jr., Director and Assistant Director of CERC, respectively; and the direct guidance of Messrs. C. E. Chatham, Jr., Chief of WDD; and Mr. D.D. Davidson, Chief of WRB. Tests were conducted by Messrs. George F. Turk, Research Hydraulic Engineer; C. Ray Herrington, Civil Engineering Technician; Johnny Heggins, Civil Engineering Technician; and David Daily of the WES Instrumentation Services Division. This report was prepared by Mr. Turk, with a special thanks to Messrs. Jeffrey A. Melby and Ernest R. Smith, CERC.

Liaison was maintained with POD through telephone conversations and facsimile transmission during the course of the investigation. The POD Point of Contact was Mr. Pat Tom, who provided cross-sectional and underlayer block designs.

At the time of publication of this report, Director of WES was Dr. Robert W. Whalin. Commander of WES was COL Bruce K. Howard, EN. 


\section{Introduction}

\section{The Prototype}

Ofu Harbor is located on the island of Ofu, American Samoa, in the South Pacific, approximately $3,700 \mathrm{~km}$ southeast of the Hawaiian Islands. The island has a volcanic origin, and is protected by numerous large coral reefs. The harbor and protecting stone rubble-mound breakwater were originally constructed in 1975.

\section{The Problem}

In 1981 the Ofu breakwater was severely damaged by tropical storm Esau, with subsequent repairs completed in 1992. Then in 1990, Hurricane Ofa struck American Samoa and the breakwater again sustained severe damage. Before the breakwater could be rehabilitated, Hurricane Val further damaged the structure in 1991. Currently the breakwater is almost completely destroyed. Armoring and underlayers on both the harbor and sea sides require complete repair. The entrance channel and turning basin require dredging to remove stone and dredged material washed into the harbor.

\section{Purpose of Study}

At the request of the U.S. Army Engineer Division, Pacific Ocean (POD), two-dimensional (2-D) wave tests were conducted at the U.S. Army Engineer Waterways Experiment Station (WES) Coastal Engineering Research Center (CERC) to determine the stability of selected concrete armor units when placed on concrete revetment blocks and subjected to a design condition of a 17-sec, 3.47-m (11.4-ft) wave. The proposed breakwater consisted of 4.1-tonne (4.5-U.S.-ton) tribar armor units, placed on an underlayer of 1.45-tonne (1.6-U.S.-ton) 30-percent porosity blocks, secured at the crown transition with a concrete rib cap. 


\section{Test Model}

\section{Scaling of the Model}

Two-dimensional stability tests were conducted at a geometrically undissorted linear scale of 1:23, model to prototype. Scale was based on size availability of model tribars and the capabilities of the available wave generator to produce required wave heights at modeled water depths. Time relations were scaled according to Froude Model Law (Stevens et al. 1942). Model to prototype relations were derived in terms of length $l$ and time $t$ shown in Table 1.

\begin{tabular}{||l|l|l||}
\hline \hline $\begin{array}{l}\text { Table 1 } \\
\text { Model-Prototype Scale Relations (1:23 scale) }\end{array}$ \\
\hline \hline Characteristic & Dimension & $\begin{array}{l}\text { Scale Relations } \\
\text { Model:Prototype }\end{array}$ \\
\hline \hline Length & $t$ & $t_{t}=1: 23$ \\
\hline Area & $t^{2}$ & $a_{t}=1: 529$ \\
\hline Volume & $t^{3}$ & $v_{t}=1: 12,167$ \\
\hline Time & $I^{12}$ & $t_{t}=1: 4.8$ \\
\hline
\end{tabular}

The specific weight of water used in the model was $1,002 \mathrm{~kg} / \mathrm{m}^{3}(62.4 \mathrm{pcf})$, with that of the prototype being $1,027 \mathrm{~kg} / \mathrm{m}^{3}$ ( $\left.64 \mathrm{pcf}\right)$. The specific weights of the model material used for construction differed for the prototype; therefore, the Hudson (1975) transference equation was used to determine model material weights as follows: 


$$
\frac{\left(W_{a}\right)_{m}}{\left(W_{a}\right)_{p}}=\frac{\left(\gamma_{a}\right)_{m}}{\left(\gamma_{a}\right)_{p}}\left(\frac{l_{m}}{l_{p}}\right)^{3}\left[\frac{\left(S_{a}\right)_{p}-1}{\left(S_{a}\right)_{m}-1}\right]^{3} .
$$

in which the subscripts $m$ and $p$ refer to model and prototype quantities, respectively, with

$$
\begin{aligned}
& W_{a}=\text { weight of individual armor unit } \\
& \gamma_{a}=\text { specific weight of an individual armor unit } \\
& l_{m} \lambda_{p}=\text { linear scale of the model } \\
& S_{a}=\text { the specific gravity of an individual armor unit relative to the } \\
& \quad \text { water in which it is placed, } S_{a}=\gamma_{d} \gamma_{w} \\
& \gamma_{w}=\text { specific weight of water }
\end{aligned}
$$

When constructing all small-scale physical models of rubble mounds, scale effects of viscous forces associated with flow through the underlayers and core of the structure are of concern. In the reproduction of prototype conditions, the model materials need to be properly sized to avoid Reynolds and other scale effects. Selected scaling was based on available armor sizes and checked for scale effects following the methods put forth by Keulegan (1973). The geometrically scaled underlayer size was found to be satisfactory. The core size, scaled from limited information on the true prototype condition, was modeled using coarse sand. This sizing allows for a conservative design with no transmission and maximum reflection. Sizes of prototype and model breakwater armor and underlayer materials are listed in Table 2.

\begin{tabular}{|l|l|l||}
\hline $\begin{array}{l}\text { Table 2 } \\
\text { Prototype and Model Material Sizes }\end{array}$ \\
\hline \hline & \multicolumn{1}{|c|}{ Prototype } & \multicolumn{1}{|c|}{ Model } \\
\hline \hline Armor Type & $\begin{array}{l}\text { Tribar } \\
4.1 \text { tonnes (4.5 U.S. tons) }\end{array}$ & $\begin{array}{l}\text { Tribar } \\
285.8 \mathrm{~g}(0.63 \mathrm{lb})\end{array}$ \\
\hline Underlayer, $\mathrm{W}_{1}$ & $\begin{array}{l}\text { 30\% Porosity block } \\
1.45 \text { tonnes (1.6 U.S. tons) }\end{array}$ & $\begin{array}{l}30 \% \text { Porosity block } \\
105.7 \mathrm{~g}(0.233 \mathrm{lb})\end{array}$ \\
\hline Underlayer, $\mathrm{W}_{2}$ & $\begin{array}{l}\text { Stone } \\
91-182 \mathrm{~kg}(200-400 \mathrm{lb})\end{array}$ & $\begin{array}{l}\text { Stone } \\
11.3 \mathrm{~g}(0.025 \mathrm{lb})\end{array}$ \\
\hline Underlayer, $\mathrm{W}_{3}$ & $\begin{array}{l}\text { Stone } \\
0.45-45 \mathrm{~kg}(1-100 \mathrm{lb})\end{array}$ & $\begin{array}{l}\text { Stone } \\
1.8 \mathrm{~g}(0.004 \mathrm{lb})\end{array}$ \\
\hline Core, $\mathrm{W}_{4}$ & $\begin{array}{l}\text { Coral Dredged Material } \\
<0.45 \mathrm{~kg}(1 \mathrm{lb})\end{array}$ & $\begin{array}{l}\text { Coarse sand } \\
\mathrm{D}_{50}=2 \mathrm{~mm}(0.08 \mathrm{in})\end{array}$ \\
\hline
\end{tabular}




\section{Test Facilities and Equipment}

Tests were conducted in a 47.2-m-long, 0.6-m-wide, 1.8-m-deep wave tank. Figure 1 shows tank dimensions, bottom slopes, wave gauge placement, and structure location for stability tests. The $1 \mathrm{~V}: 20 \mathrm{H}$ seaward slope transitioned to a flat reef, using a $1 \mathrm{~V}: 1 \mathrm{H}$ slope, to represent local bathymetry seaward of the breakwater location. The structure was located at a prototype shoreward

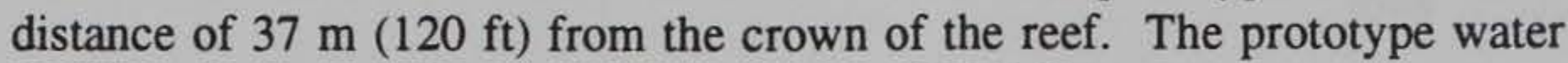
depth at the toe of the structure was $3.9 \mathrm{~m}(12.9 \mathrm{ft})$.

Waves were generated by a hinge-type electronically controlled hydraulic wavemaker. Displacement of the wave board was controlled by a command signal transmitted to the wave board by a Digital Equipment Corporation MicroVax II computer. Waves were produced by the periodic displacement of the wave board. Regular wave signals were produced by a synthesized function generator, which can generate sine waves. Several random wave tests were conducted where command signals to drive the wave board were generated to simulate a Texel Marsen Arsloe (TMA) shallow-water spectrum (Hughes 1984) for several wave periods.

\section{Breakwater Test Section}

The configuration of the modeled 2-D cross section (Figure 2) simulated a representative prototype section of the reach between Sta. $4+00$ and $6+72$ (Figure 3 ). The breakwater cross section consists of a typical trapezoidal geometry. Tribars are used to armor both the sea side and lee side of the structure (Figure 4). They lay atop the first underlayer, specially fabricated concrete 30-percent porosity blocks. The second and third stone underlayers protect the coral dredged material core. The structure is capped with a concrete rib cap typical of many POD concrete armored structures.

A major task during this modeling effort was the construction of the 30 -percent porosity blocks (Figure 5) used in place of underlayer stone. In order to remain on schedule and expedite the effort, the blocks were modeled using oak ballasted with lead. Using this method, the geometry, weight, and weight density were satisfactorily modeled at a 1:23 scale, achieving a scaled prototype weight of 1.45 tonnes (1.6 U.S. tons), and a weight density of $2,246 \mathrm{~kg} / \mathrm{m}^{3}$ (140 pcf). For the blocks, the mean unit weight tolerance was within 4 percent of the target weight of $105.7 \mathrm{~g}(0.233 \mathrm{lb})$ with a standard deviation of \pm 3 percent.

The materials used for the core and stone underlayers were placed by hand, smoothed to grade, and compacted with hand trowels to simulate consolidation that would have occurred due to wave action. The 30 -percent porosity blocks and tribar armor layer were then placed on the structure. The rib cap (Figure 6) was constructed at a 1:23 geometric scale. This was secured to tie-downs placed in the model base to prevent movement. 


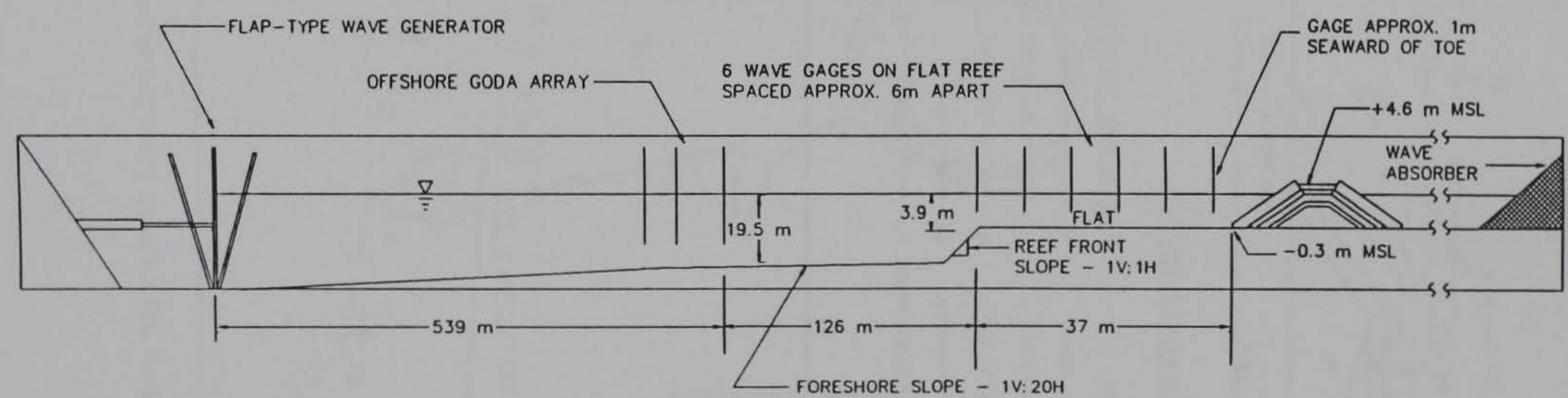

Figure 1. Flume layout 


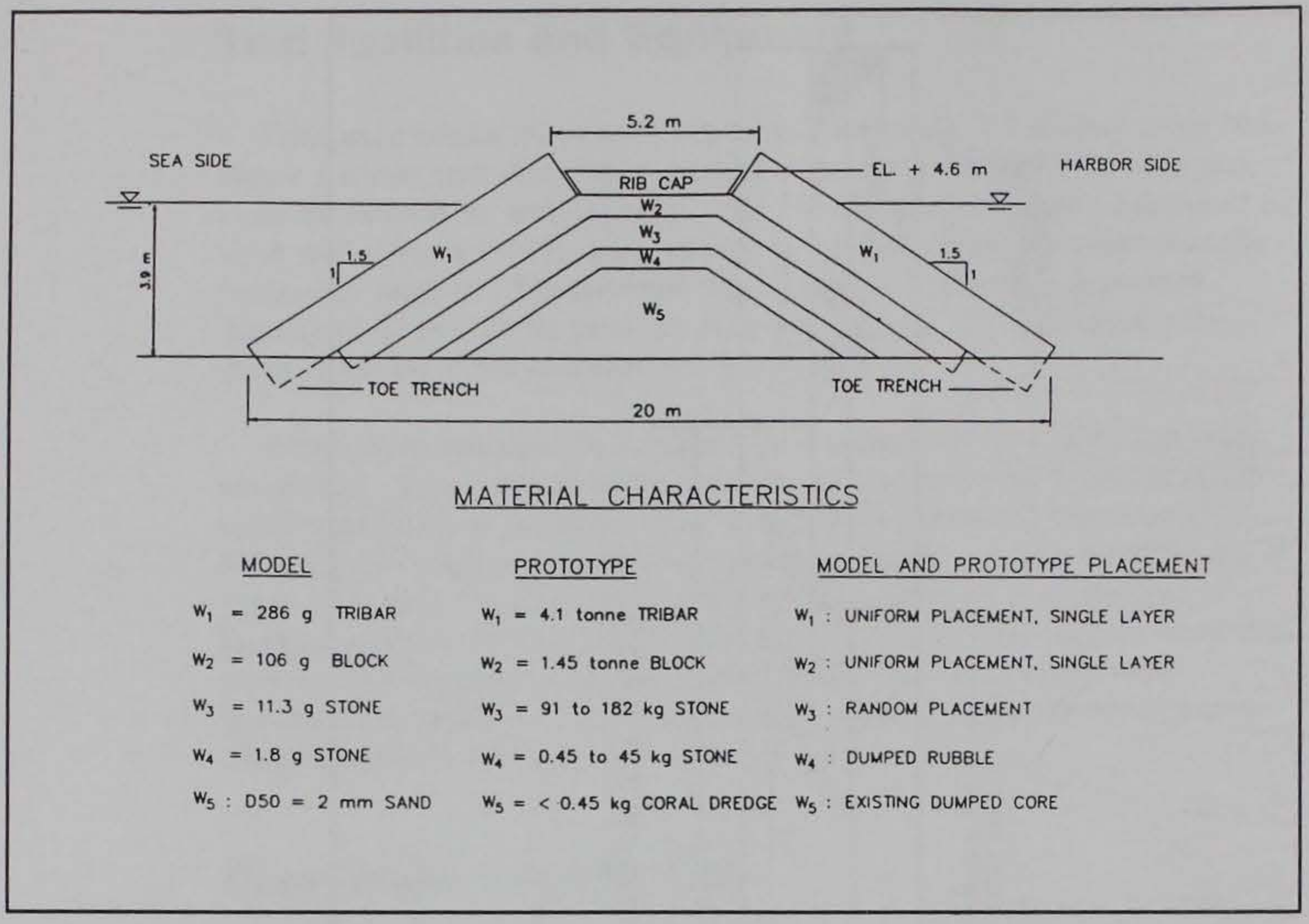

Figure 2. Breakwater configuration 


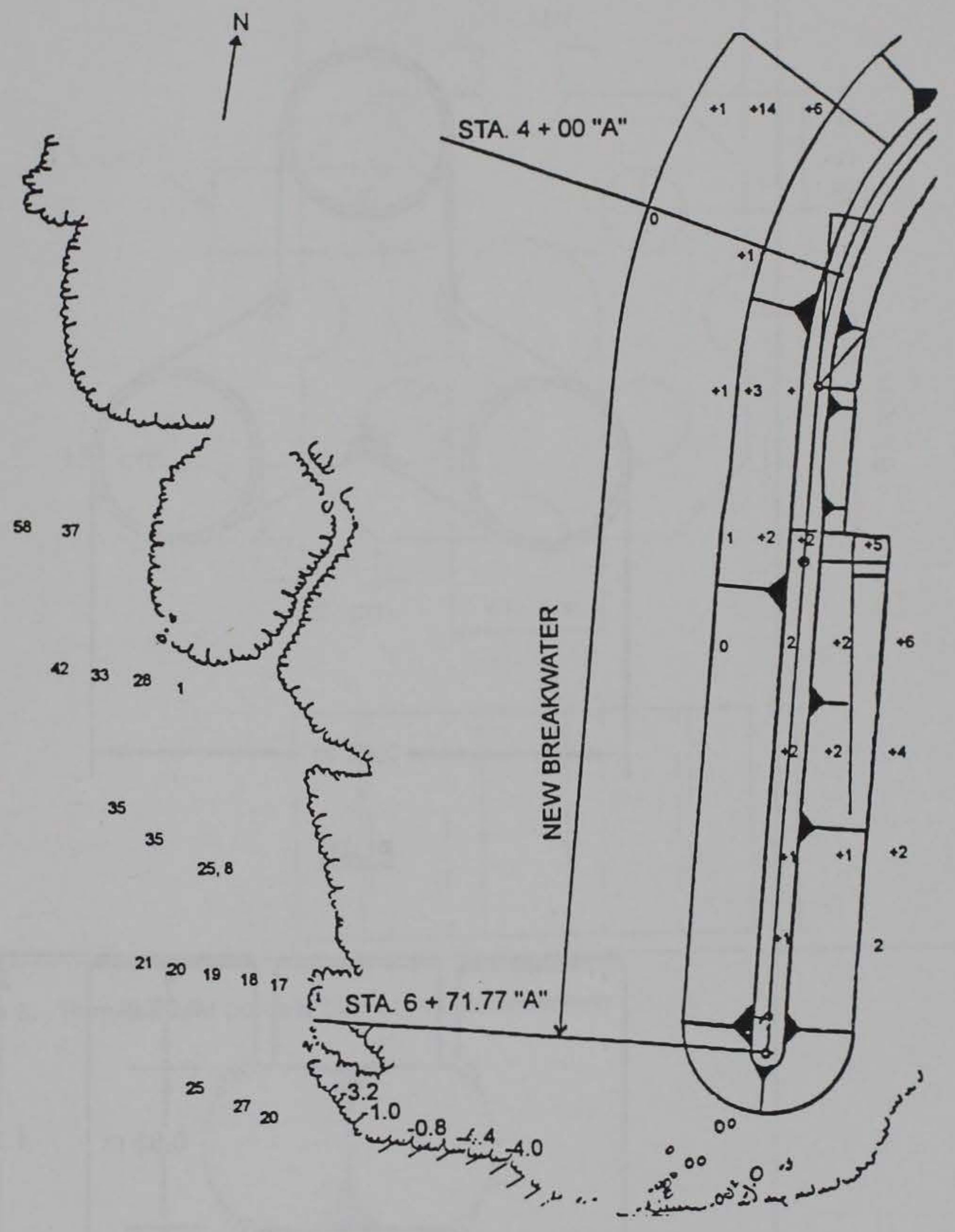

Figure 3. Ofu breakwater alignment between Sta. $4+00$ and Sta. $6+72$ 


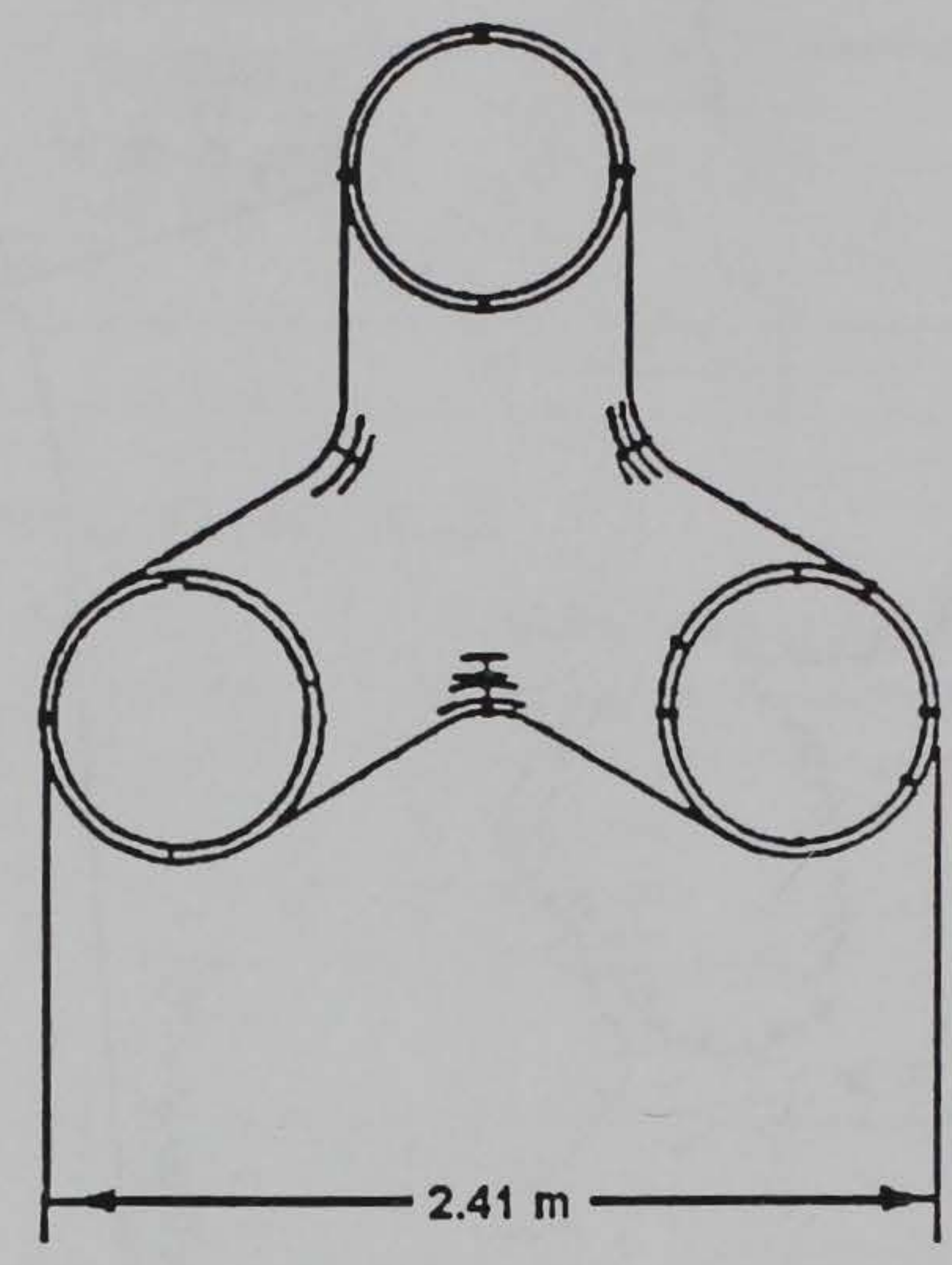

PLAN

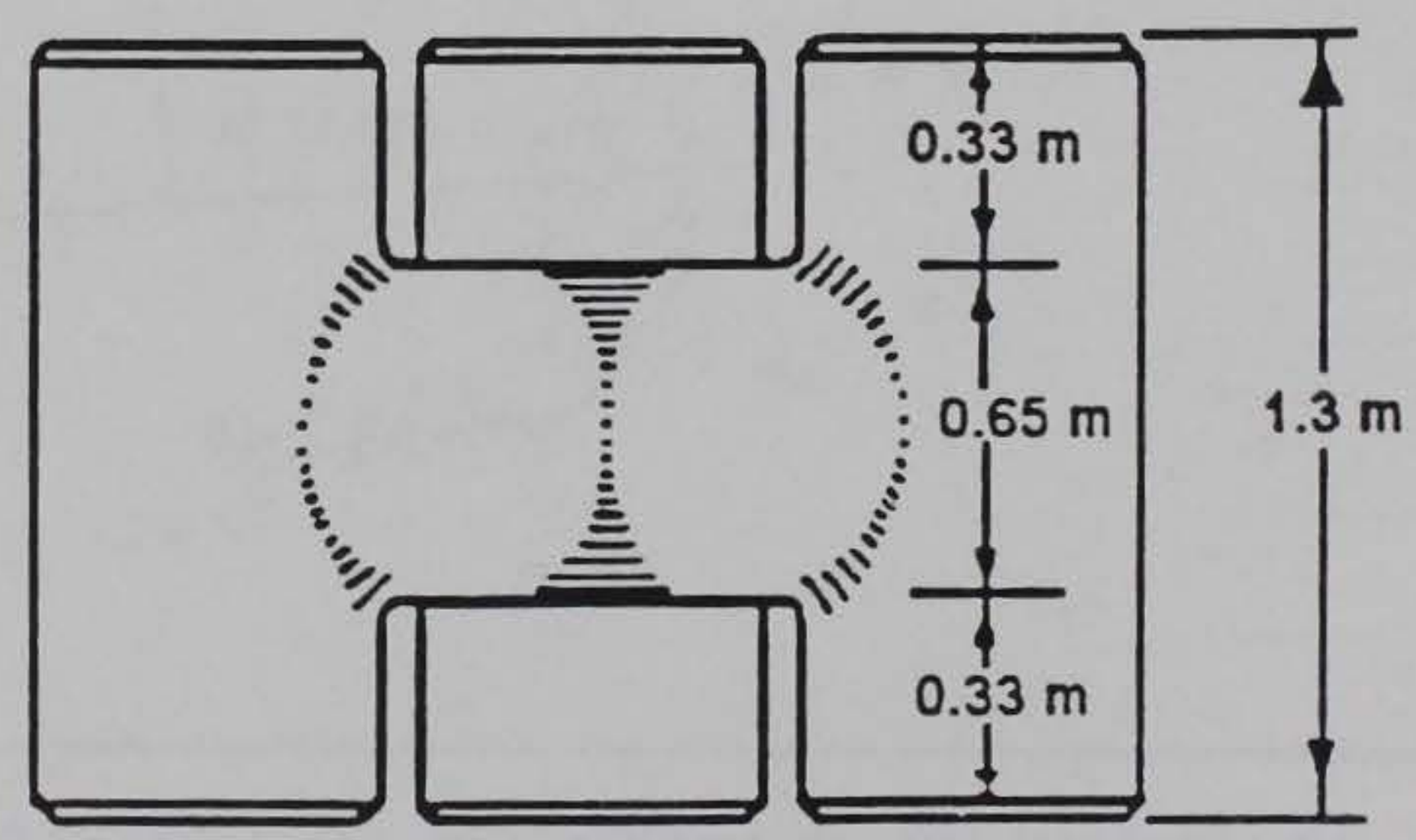

ELEVATION 


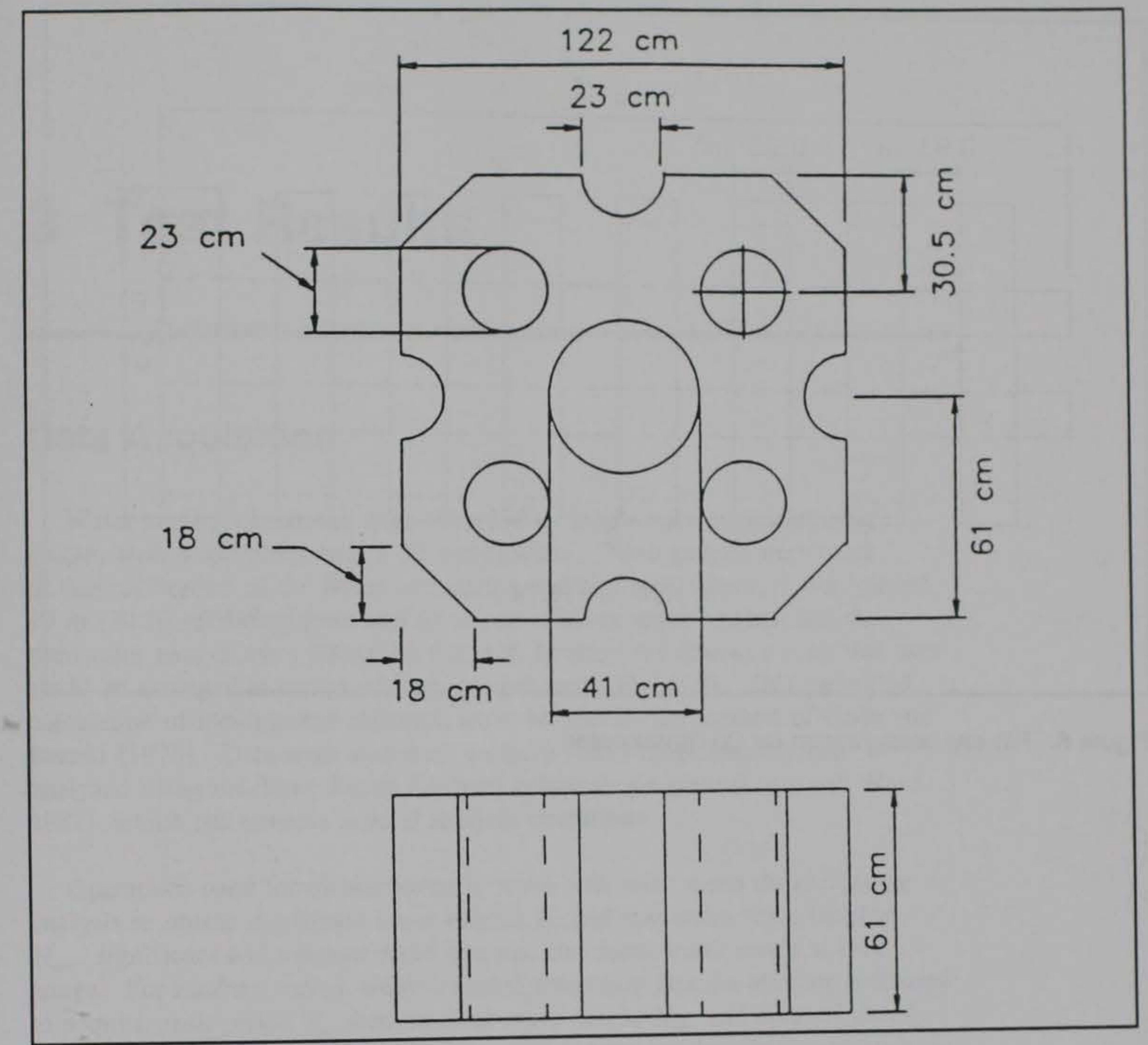

Figure 5. Thirty-percent porosity block used for underlayer 


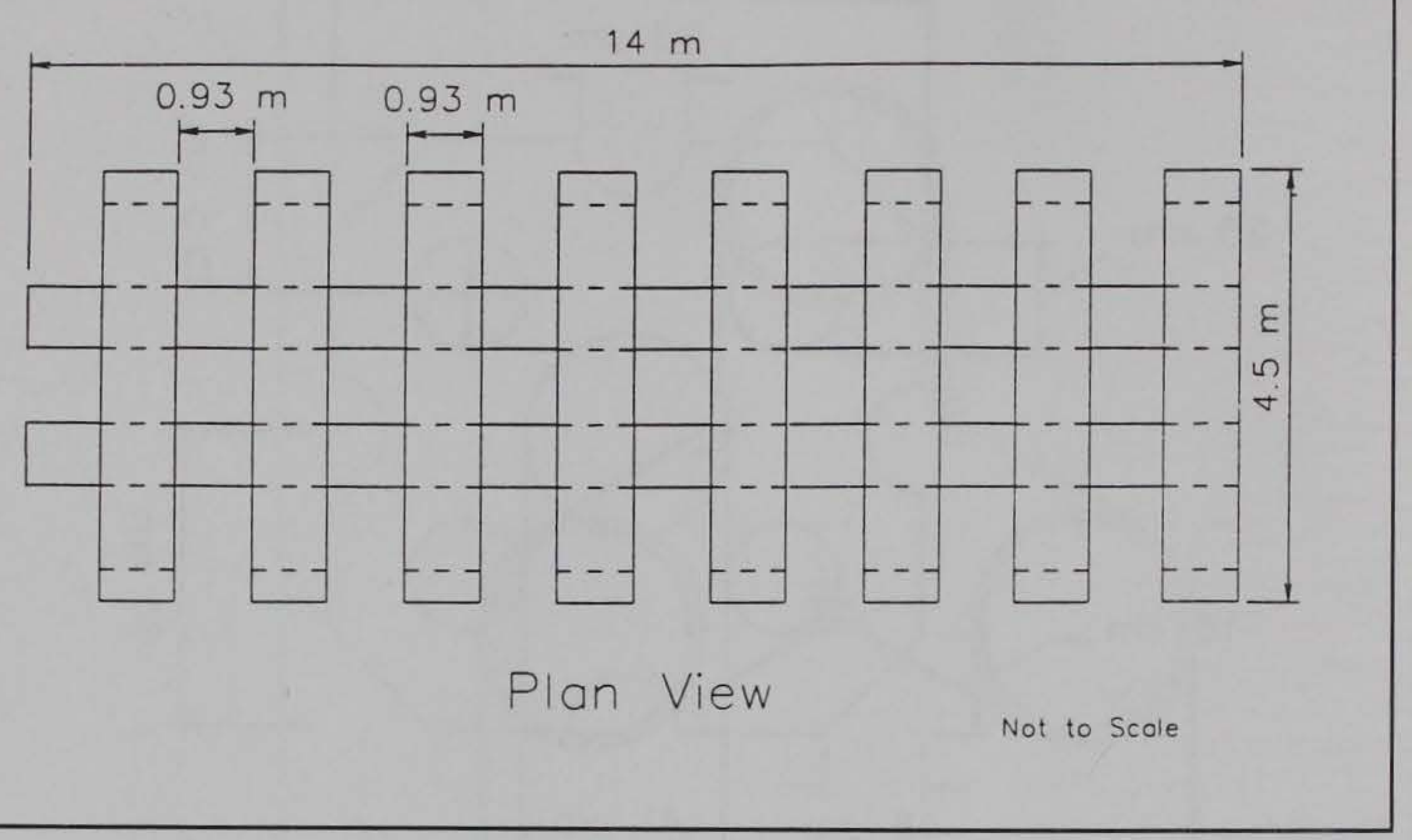

Figure 6. Rib cap configuration for Of breakwater

10

Chapter 2 Test Model 


\section{Test Results}

\section{Data Acquisition}

Water surface elevations were recorded by single wire capacitance-type gauges with a sampling rate of 20 samples/sec. Nine gauges were used during calibration of the flume and during stability tests. Array 1 was placed

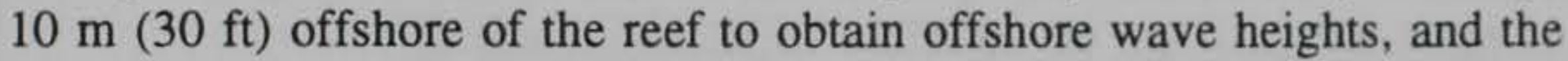
remaining gauges were placed on the reef, fronting the structure such that they could be arranged in arrays of three gauges each (Figure 1). This permitted calculation of incident and reflected wave heights by the method of Goda and Suzuki (1976). Data were stored on a MicroVax II minicomputer and analyzed using the Time Series Analysis computer program (Long and Ward 1987), which can execute several analysis operations.

Operations used for monochromatic wave tests were mean downcrossing analysis to obtain significant wave heights $H_{s}$ and maximum wave heights $H_{\max }$, significant and average wave periods, and mean water levels at each gauge. For random waves, single-channel frequency domain analysis was used to acquire peak period $T_{p}$, zero-moment wave height $H_{m o}$, and spectral density plots for each gauge. Unidirectional spectral density incident/reflection analysis was used to determine incident and reflected wave heights at each array.

\section{Calibration/Test Conditions/Wave Height Determination}

The wave generator was calibrated for both monochromatic and random waves without the breakwater in place. A three-gauge array was positioned offshore. To determine wave heights on the reef, a second array was placed at the toe of the breakwater. The calibration was for several wave periods and heights, windowing the $17-\mathrm{sec}, 3.47-\mathrm{m}(11.4-\mathrm{ft})$ prototype design wave condition at a prototype water depth of $3.9 \mathrm{~m}(12.9 \mathrm{ft})$ at the breakwater toe. Calibration runs provided a baseline of attainable wave heights for each wave period. 
Calibration also allowed a comparison between offshore wave height and wave heights on the reef prior to placing the structure. Using the two Goda arrays during the initial calibration and a single offshore array and six single wave gauges on the reef once the structure was in place permitted calculation of reflection coefficients for the reef and structure.

While the scope of work requested testing with only monochromatic waves for a design wave period of $17 \mathrm{sec}$ and wave height of $3.47 \mathrm{~m}(11.4 \mathrm{ft}$, if it could be obtained at the specified water depth of $3.9 \mathrm{~m}$ ), the author felt it prudent to establish the most severe breaking wave conditions, for a range of selected periods that may break on the structure.

Figures 7-13 show significant monochromatic wave heights attained during calibration runs, both offshore and on the reef at the toe of the structure. In general, the shorter period waves ( $\leq 15 \mathrm{sec}$ ) tended to shoal more quickly and break nearer the edge of the reef. For longer period waves $(15-18 \mathrm{sec})$, the wave would shoal and break in the vicinity of the location where the structure would be placed. The 20 -sec wave period was limited by the wave generator stroke and did not break near the structure location proposed.

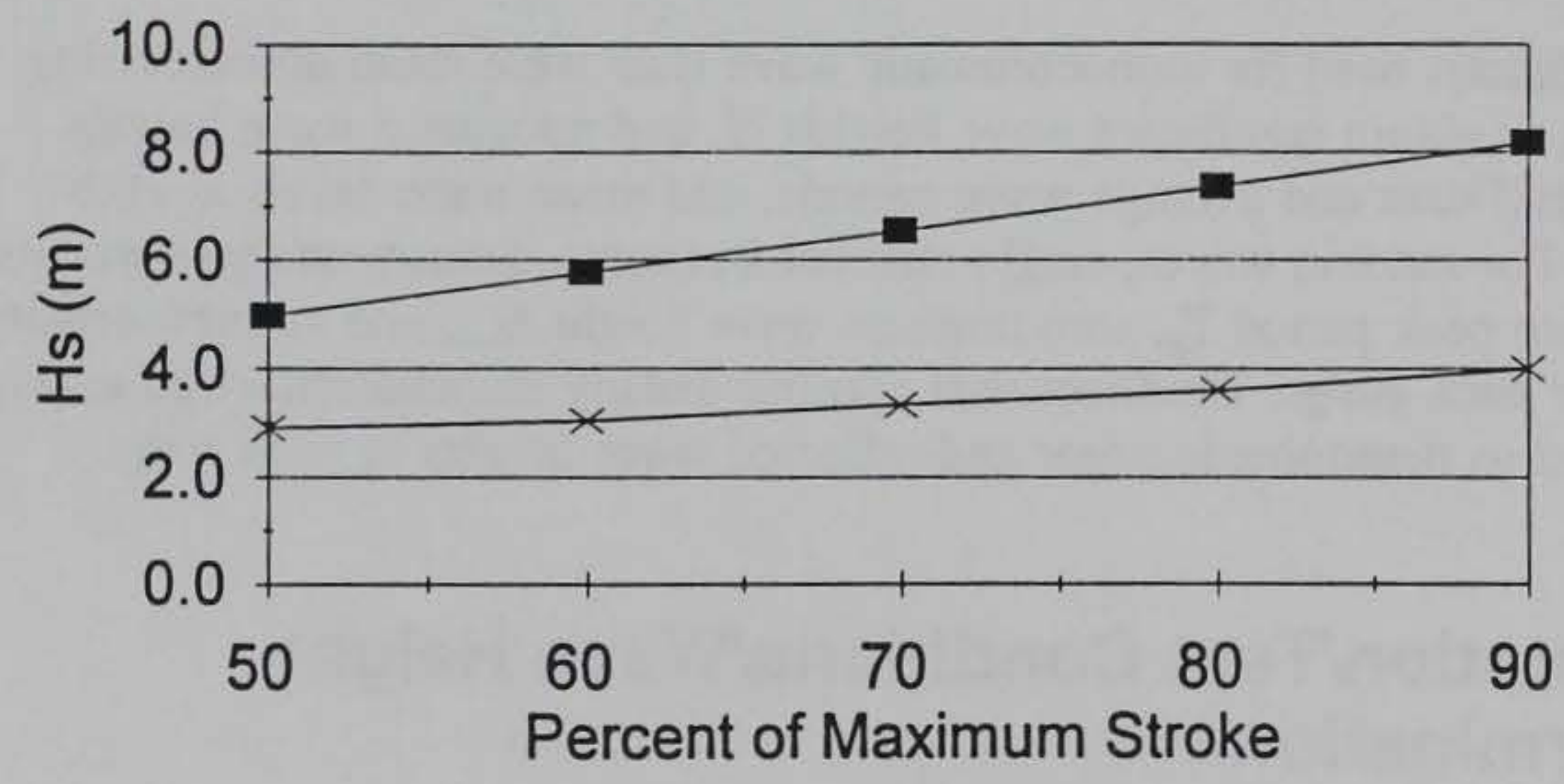

Hs Offshore $\quad *$ Hs on Reef @ toe

Figure 7. Wave heights as a function of board stroke, $T=9 \mathrm{sec}$ 


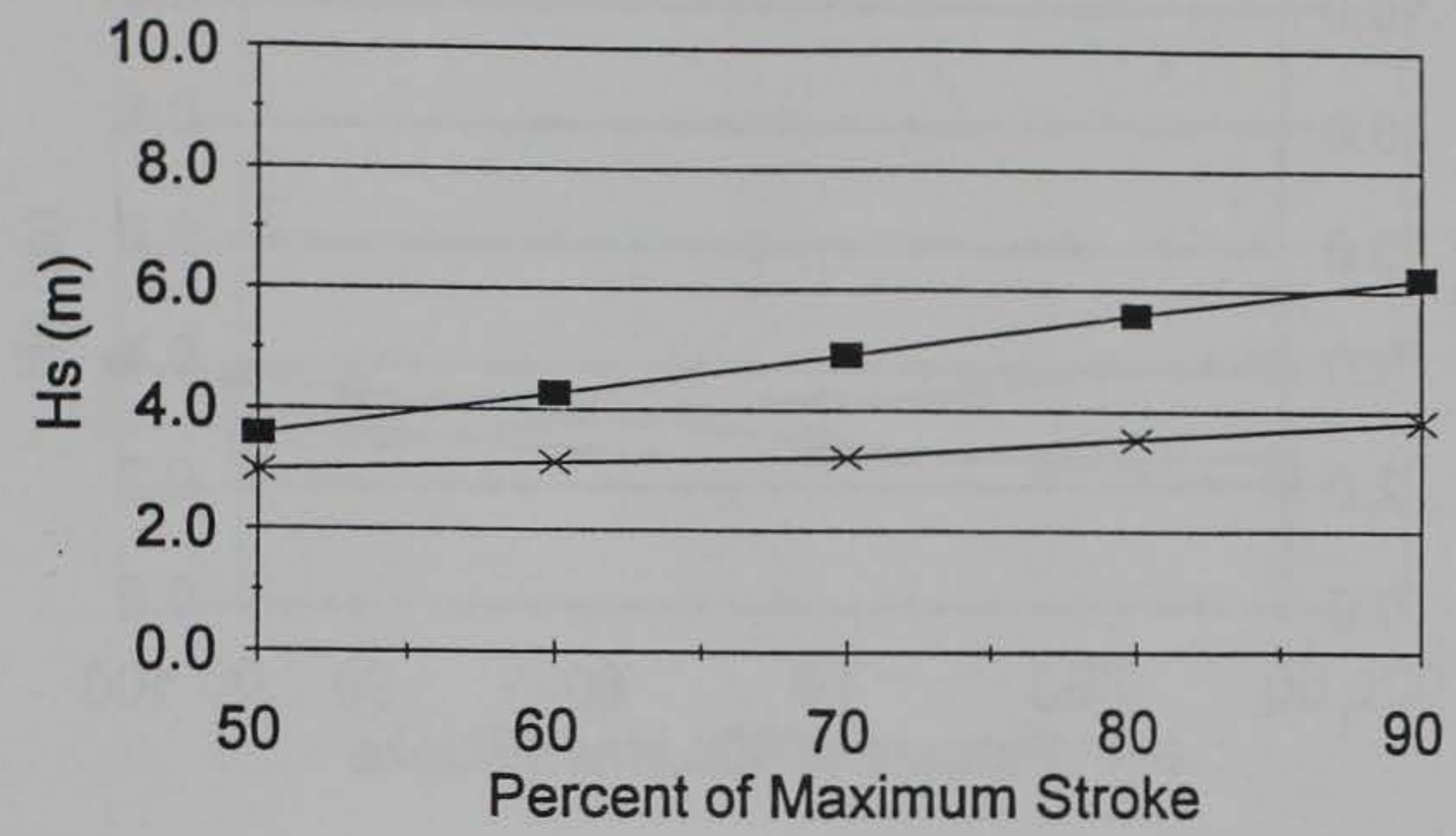

- Hs Offshore $\quad *$ Hs on Reef @ toe

Figure 8. Wave heights as a function of board stroke, $T=11 \mathrm{sec}$

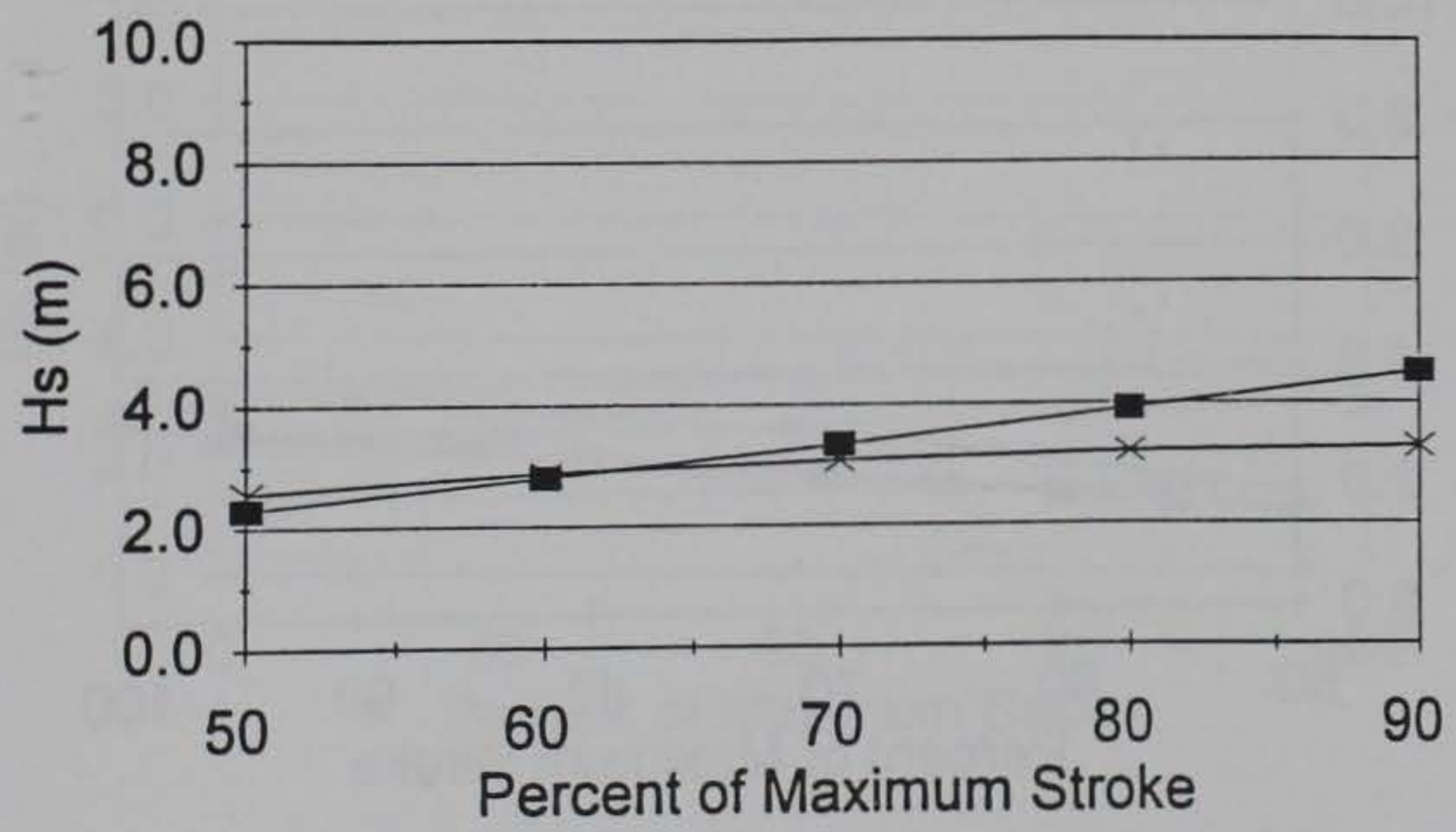

- Hs Offshore $\quad *$ Hs on Reef @ toe

Figure 9. Wave heights as a function of board stroke, $T=13 \mathrm{sec}$ 


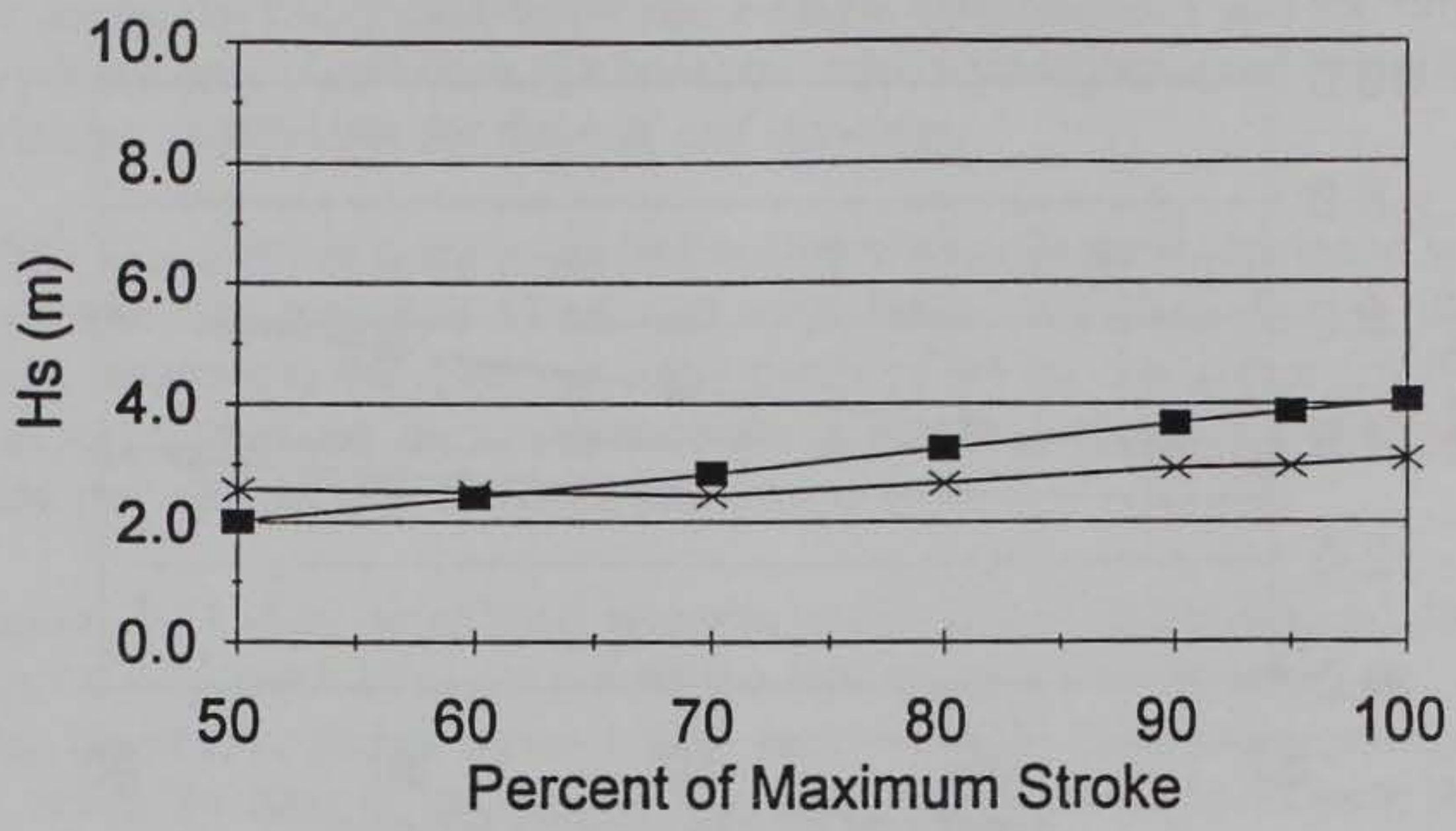

Hs Offshore * Hs on Reef @ toe

Figure 10. Wave heights as a function of board stroke, $T=15 \mathrm{sec}$

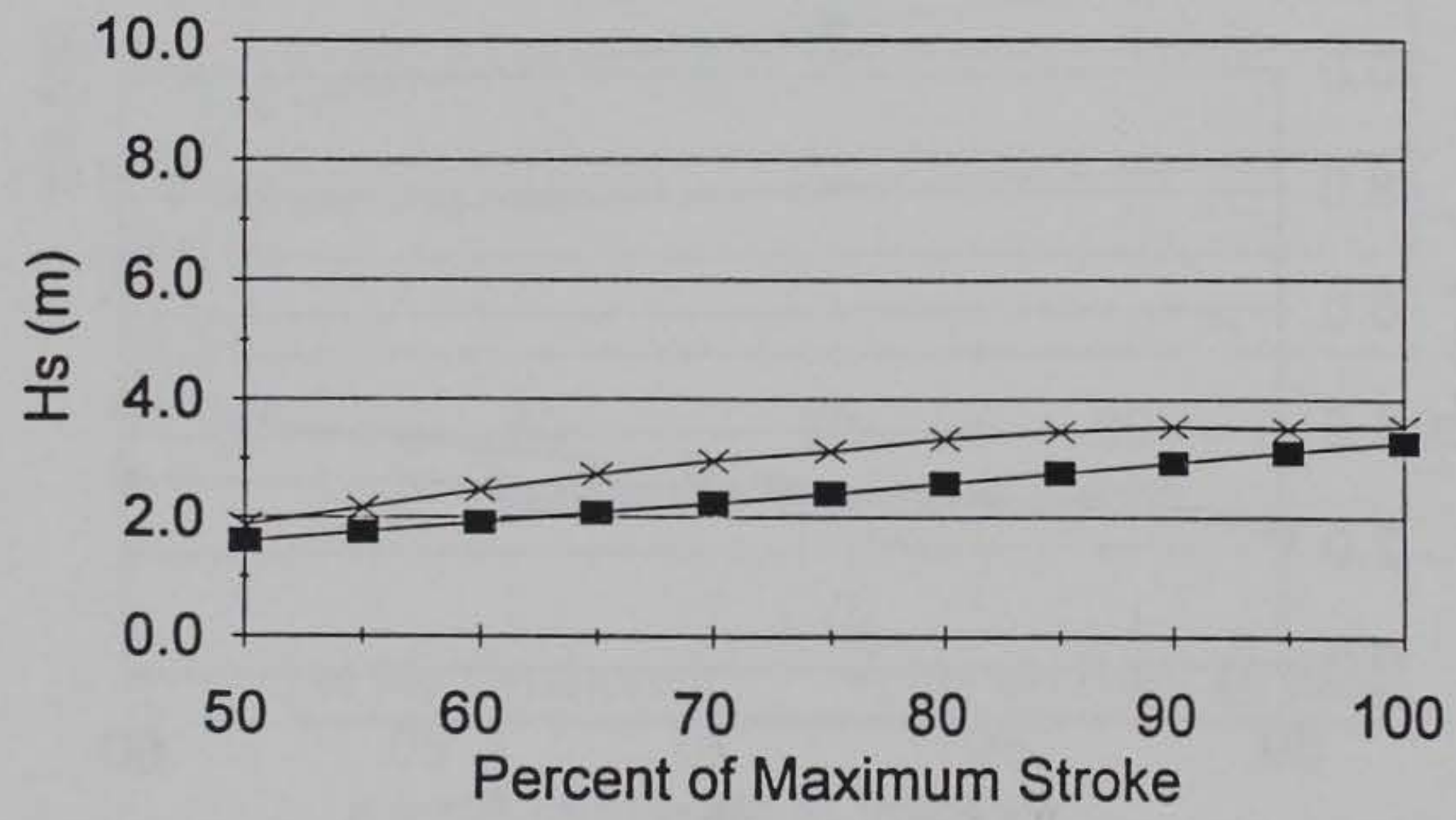

- Hs Offshore $\quad *$ Hs on Reef @ toe

Figure 11. Wave heights as a function of board stroke, $T=17 \mathrm{sec}$ 


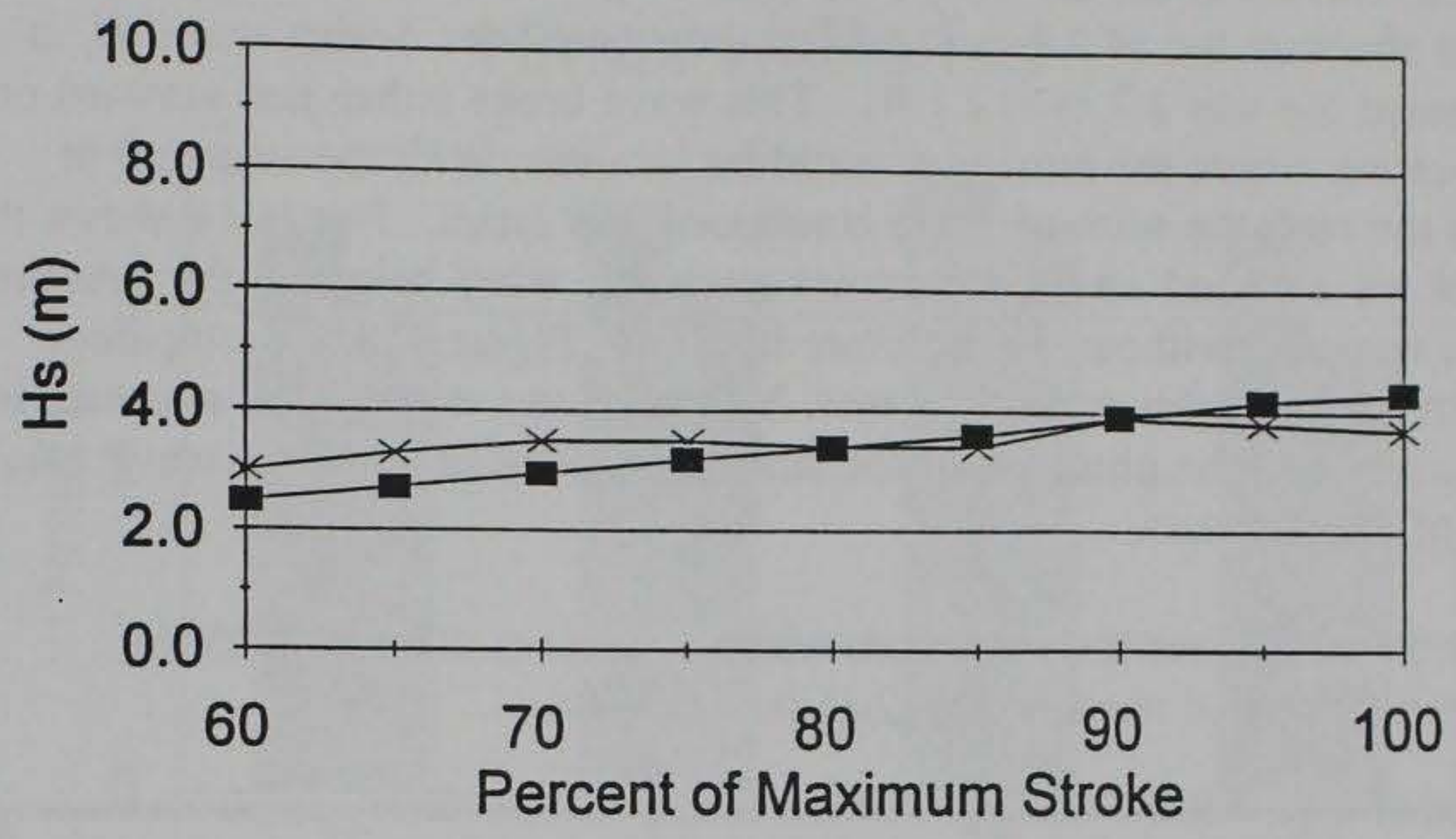

- Hs Offshore $\quad *$ Hs on Reef @ toe

Figure 12. Wave heights as a function of board stroke, $T=18 \mathrm{sec}$

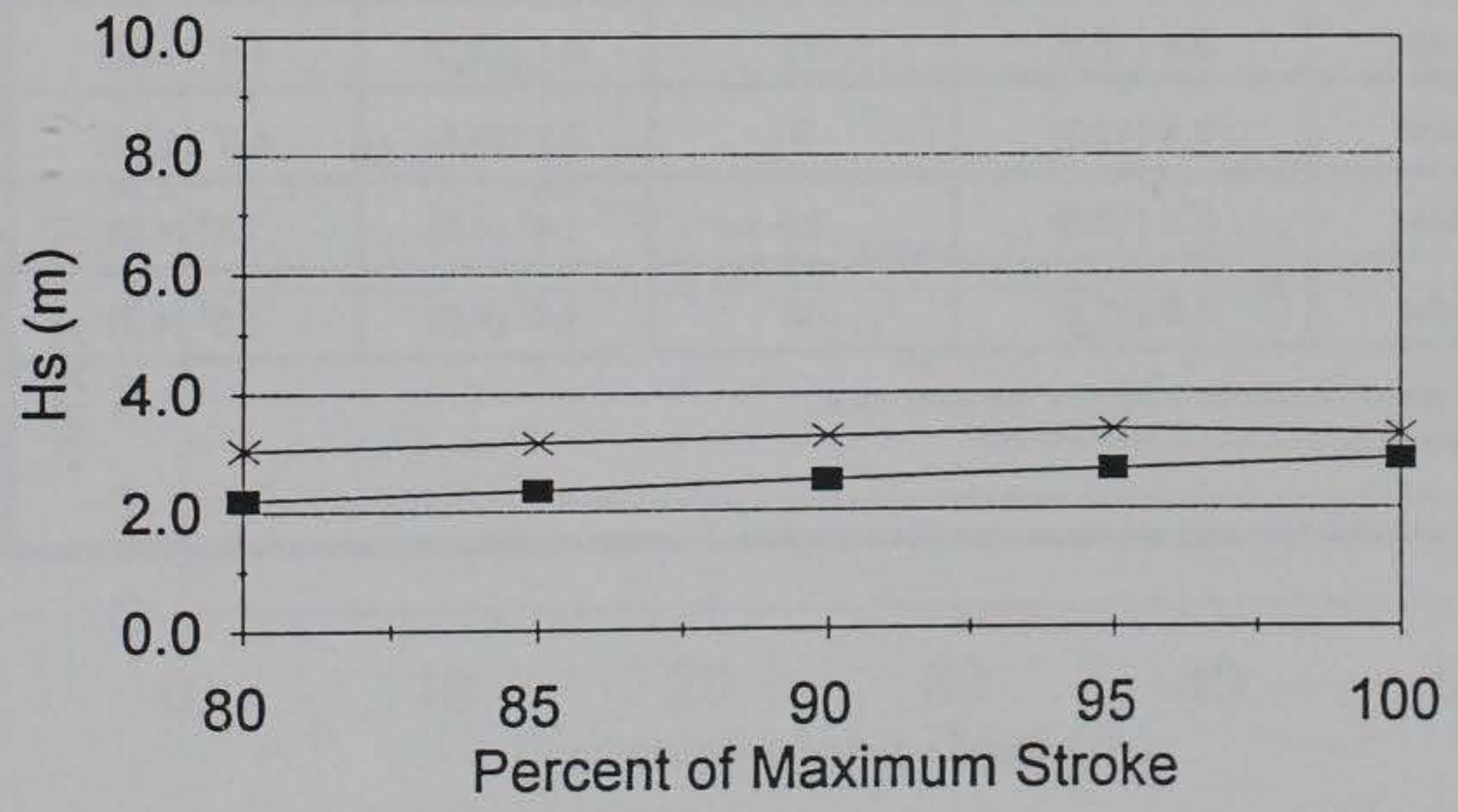

- Hs Offshore $\quad *$ Hs on Reef @ toe

Figure 13. Wave heights as a function of board stroke, $T=20 \mathrm{sec}$ 
During calibration without the structure, the most energetic and maximum achievable wave was the 18 -sec wave, with a significant wave height $H_{s}$ at the proposed structure toe of $3.9 \mathrm{~m}(12.8 \mathrm{ft})$. For the $17-\mathrm{sec}$ design wave, $H_{s}$ at the proposed toe was $3.7 \mathrm{~m}(12.1 \mathrm{ft})$. This wave broke either just seaward or at the location where the structure would be located. With the structure in place on the reef, the suite of wave conditions was rerun. Figure 14 shows the effects of wave period on the maximum attainable wave height at the structure toe, both with and without the structure in place. Figures 15-18 compare maximum wave heights across the reef, both with and without the structure in place. In general, the presence of the structure tended to attenuate wave height in front of the structure.

Table 3 summarizes the maximum wave conditions attained with the structure in place and used for the 2-D stability test.

\begin{tabular}{|c|c|c|c|c|}
\hline \multicolumn{5}{|c|}{$\begin{array}{l}\text { Table } 3 \\
\text { Stability Test Wave Conditions }\end{array}$} \\
\hline Wave Type & $\begin{array}{c}\text { Water Depth } \\
\text { m, (ft) }\end{array}$ & $\begin{array}{c}\text { Wave Period } \\
\text { sec }\end{array}$ & $\begin{array}{c}H_{0} \text { - Offshore } \\
\mathrm{m},(\mathrm{ft})\end{array}$ & $\begin{array}{c}\mathrm{H}_{\mathbf{s}}-\text { at Structure } \\
\mathrm{m},(\mathrm{ft})\end{array}$ \\
\hline Regular & $3.9(12.8)$ & 20 & $2.6(8.5)$ & $2.8(9.2)$ \\
\hline Regular & $3.9(12.8)$ & 18 & $4.2(13.8)$ & $3.9(12.8)$ \\
\hline Regular & $3.9(12.8)$ & 17 & $3.6(11.8)$ & $3.7(12.1)$ \\
\hline Regular & $3.9(12.8)$ & 15 & $4.0(13.1)$ & $3.0(9.8)$ \\
\hline Regular & $3.9(12.8)$ & 13 & $4.3(14.1)$ & $3.2(10.5)$ \\
\hline Regular & $3.9(12.8)$ & 11 & $6.1(20.0)$ & $3.9^{\prime}(12.8)$ \\
\hline Regular & $3.9(12.8)$ & 9 & $8.1(26.6)$ & $4.0^{\prime}(13.1)$ \\
\hline Irregular & $3.9(12.8)$ & 7.2 & $1.4^{2}(4.6)$ & $1.5^{2}(4.9)$ \\
\hline Irregular & $3.9(12.8)$ & 12 & $1.4^{2}(4.6)$ & $1.5^{2}(4.9)$ \\
\hline \multicolumn{5}{|c|}{$\begin{array}{l}\text { These waves broke on reef, not on structure. } \\
{ }^{2} H_{m o} \text { wave height. }\end{array}$} \\
\hline
\end{tabular}




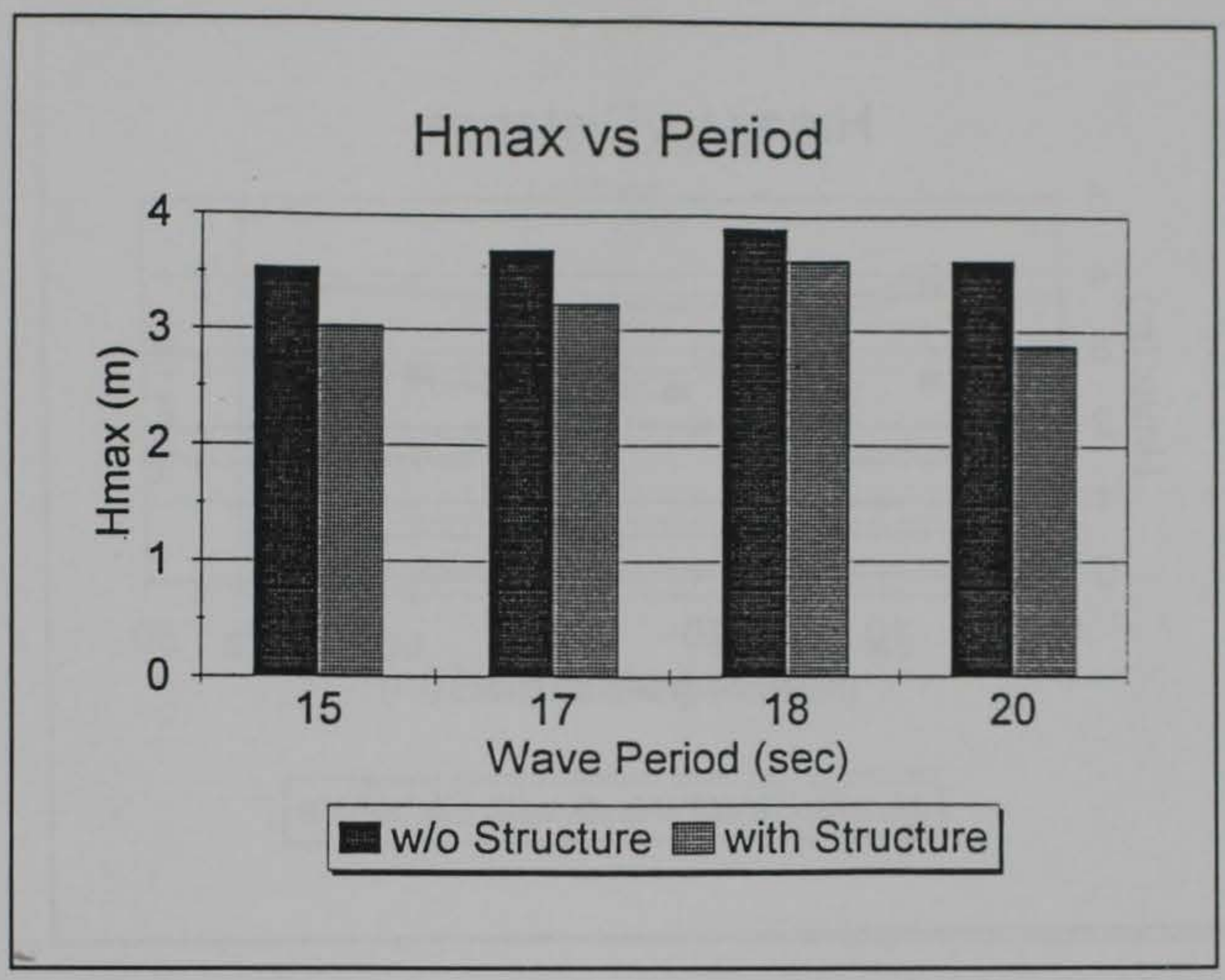

Figure 14. Maximum attainable wave height on reef at structure toe

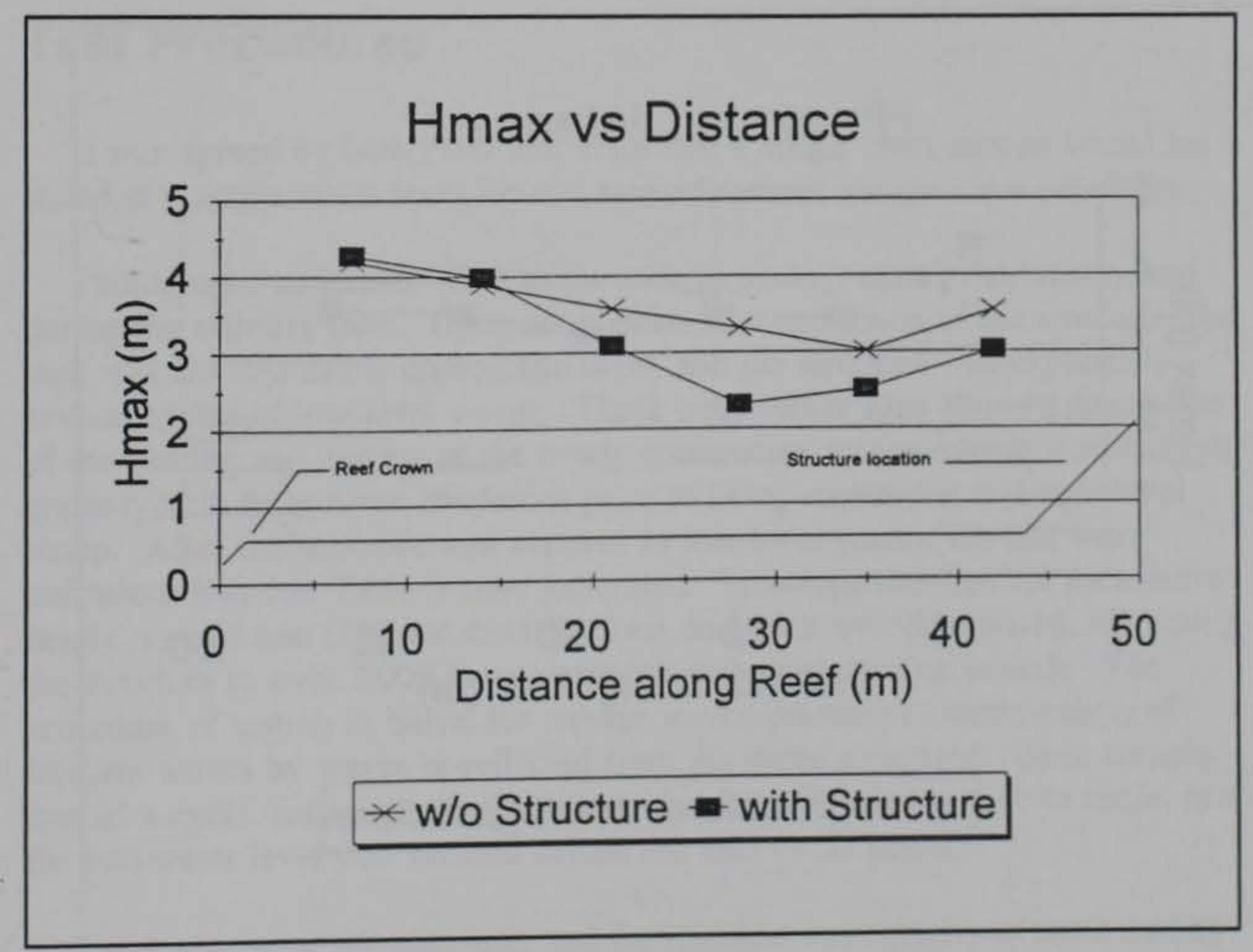

Figure 15. Wave transformation on reef for $T=15 \mathrm{sec}$ 


\section{Hmax vs Distance}

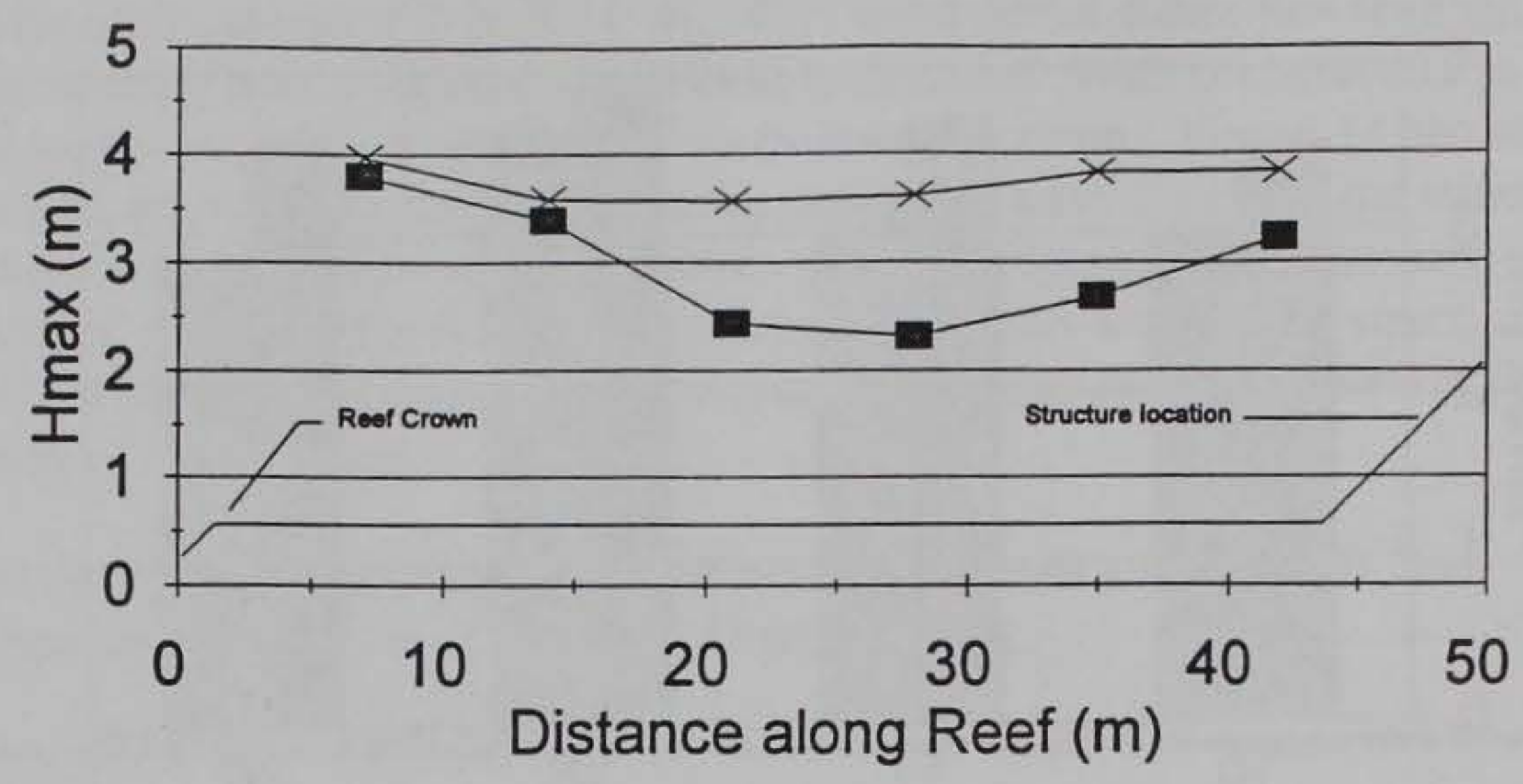

$*$ w/o Structure $=$ with Structure

Figure 16. Wave transformation on reef for $T=17 \mathrm{sec}$

\section{Hmax vs Distance}

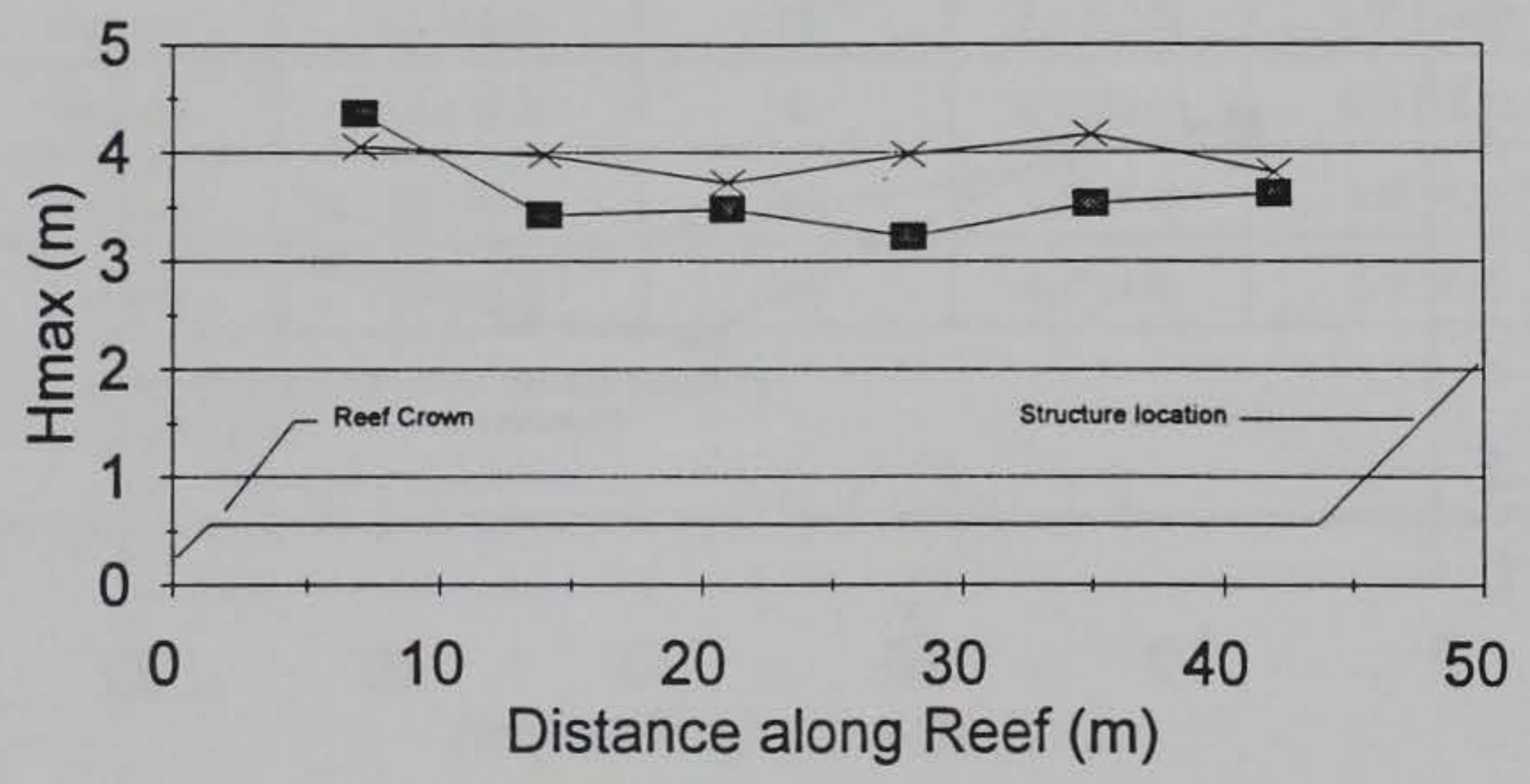

$*$ w/o Structure $=$ with Structure

Figure 17. Wave transformation on reef for $T=18 \mathrm{sec}$ 


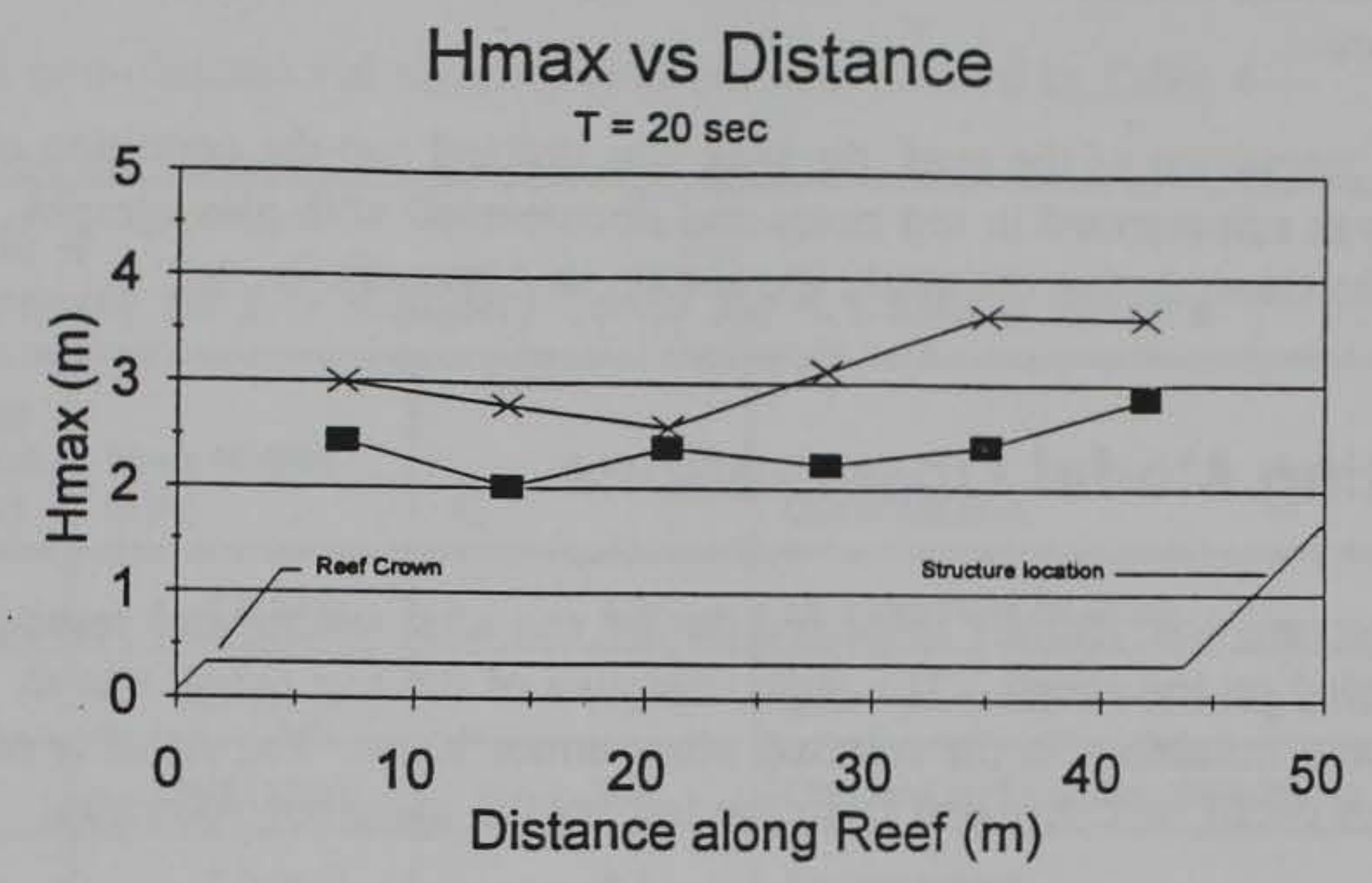

$*$ w/o Structure $=$ with Structure

Figure 18. Wave transformation on reef for $T=20 \mathrm{sec}$

\section{Test Procedures}

It was agreed by both POD and WES that a single cross section would be tested at a single water level for one monochromatic design wave condition.

Photographs and video were taken prior to testing, during calibration, and during the stability tests. Upon completion of construction of the structure, the tank was flooded to the appropriate depth and the structure was exposed to several cycles of low-level waves. These initial wave runs allowed simulation of the settling and nesting of the newly constructed section which would occur under typical daily wave conditions prior to being exposed to a design level storm. After the structure was exposed to low-level waves, the test wave conditions listed in Table 3 were generated. Prototype duration for each wave height was $14 \mathrm{~min}$ (180 sec model). Test durations were completed, subjecting the structure to over 2,000 monochromatic waves of varying periods. The procedure of testing in bursts for regular waves prevented contamination of incident waves by waves re-reflected from the wave generator. Upon completion of a cycle, sufficient time was provided for the water surface to settle, and the still-water level was verified before the next cycle began.

The response of the structure, and the location and severity of the breaking waves to each cycle of test waves were recorded. Detailed model observation included movement of units on the structure and a general statement of the overall stability of the structure. The armor slope was reconstructed twice. 
The purpose of the repeat test was to determine the presence of any uncontrolled variations in model construction technique that might affect stability of the structure.

At the conclusion of the tests, the tank was drained and the condition of the structure was summarized in test notes and documented with photographs. Photographs taken during the study are shown in Appendix A.

\section{Reporting Model Observations}

The structure was visually inspected during and after testing and results were recorded on log sheets. The main objective of the test series was to check for any instability in the selected tribar armor layer. The stability of the test sections could be calculated from the test results using the following formula:

$$
K_{d}=\frac{\gamma_{a} H^{3}}{W_{a}\left(S_{a}-1\right)^{3} \cot \theta}
$$

where

$K_{d}=$ Hudson stability coefficient

$H$ = wave height at the structure that causes no damage, i.e., wave height at which damage is less than or equal to 2 percent of the number of primary armor units placed on the respective breakwater slope

$\Theta \quad=$ angle of the structure slope measured from horizontal

$W_{a}=$ weight of an individual armor unit

$\gamma_{a} \quad=$ weight density of the armor unit

$S_{a} \quad$ = specific gravity of the armor unit

In the present study, the design wave height at the structure toe was used to calculate stability coefficients for monochromatic waves. 


\section{Summary of Two-Dimensional Stability Tests}

The two-dimensional stability tests are summarized in Table 4 .

\begin{tabular}{|c|c|c|c|}
\hline $\begin{array}{c}\text { Wave } \\
\text { Period } \\
\text { (sec) }\end{array}$ & $\begin{array}{l}\text { Wave Height } \\
\mathrm{m} \text {,(ft) }\end{array}$ & $K_{d}$ & Observations \\
\hline 20.0 & $2.8(9.2)$ & 4.2 & No movement on slope \\
\hline 18.0 & $3.9(12.8)$ & 11.3 & Maximum of two units rocking on slope \\
\hline 17.0 & $3.7(12.1)$ & 9.5 & Only one unit rocking intermittently \\
\hline 15.0 & $3.0(9.8)$ & 5.1 & No movement \\
\hline 13.0 & $3.2(10.5)$ & 6.2 & No movement \\
\hline 11.0 & $3.9^{1}(12.8)$ & 11.3 & No movement \\
\hline 9.0 & $4.0^{1}(13.1)$ & 12.1 & No movement \\
\hline $7.2^{2}$ & $1.5^{1}(4.9)$ & $>1.0$ & No movement \\
\hline $12^{2}$ & $1.5^{1}(4.9)$ & $>1.0$ & No movement \\
\hline
\end{tabular}




\section{Conclusions and Comments}

The physical model investigation of the 1:23 scale Ofu breakwater section indicates that the 4.1-tonne (4.5-ton) tribar primary armor layer will remain hydraulically stable for the specified design wave condition $(17 \mathrm{sec}, 3.47 \mathrm{~m}$ $(11.4 \mathrm{ft}))$ using a first underlayer of 1.45-tonne (1.6-ton) 30-percent porosity blocks laid flat on the slope. In addition, the most severe breaking waves that could be made to break on the structure were reproduced for wave periods from 9 to $20 \mathrm{sec}$. For any of the wave conditions tested, only mild rocking of a few units was observed.

While the test series indicates that units will remain hydraulically stable, several observations were made and the author feels it necessary to express his opinion as qualifying statements:

a. This was only a 2-D test that checked hydraulic stability of uniformly placed tribars atop an underlayer of uniformly placed manmade concrete 30 -percent porosity blocks. Tests were for primarily one design wave condition, one water depth, and one localized bathymetry. No conclusions can be drawn for units subject to multi-directional waves (head sections), stability at lateral or longitudinal transitions, larger wave loadings (typhoon conditions), changes in water depth (extreme tidal \pm , storm surge, etc.), or changes in structure geometry and/or elevations.

b. Structural integrity of the 1.45-tonne (1.6-ton) unreinforced concrete block was not addressed in this study. The possibility exists that the reduction in cross-sectional area necessary to introduce porosity for overall hydraulic stability may be detrimental to the structural strength of the block, especially if loading from overlying tribar movement or "pumping" is initiated by sustained wave attack. Care must be taken in the placement of these blocks and the tribars so as not to allow impact due to rough handling. Construction quality control must be maintained in both the casting and placement.

c. No structural guidance is available to the Corps for tribars; however, much research has been done on dolosse (another slender unit). For similar size dolosse with similar central section dimensions, a minimum concrete strength $f^{\prime} c=35 \mathrm{Mpa}(5,000 \mathrm{psi})$ (mean minus one standard 
deviation) would be specified. This assumes no impact loading. Unitto-unit impact loading must be avoided both during placement and during service life. If units are broken during placement, they must be removed and replaced with intact units. This is especially important on "laid-up" armor, which is more susceptible to unraveling than randomly placed armor, once damage is initiated.

d. Care must be taken to get a tight packing on slope, and to assure secure transition zones, meaning toe units must be well-entrenched, lateral transitions buttressed, and crown units secured by the rib cap. 


\section{References}

Goda, T., and Suzuki, Y. (1976). "Estimation of incident and reflected waves in random wave experiments." Proc. of the 15th Coastal Engrg. Conf. Honolulu, Hawaii, 828-845.

Hudson, R.Y. (1975). "Reliability of rubble-mound breakwater stability models," Miscellaneous Paper H-75-5, U.S. Army Engineer Waterways Experiment Station, Vicksburg, MS.

Hughes, S.A. (1984). "The TMA shallow-water spectrum description and applications," Technical Report CERC-84-7, U.S. Army Engineer Waterways Experiment Station, Vicksburg, MS.

Keulegan, G.H. (1973). "Wave transmission through rock structures; hydraulic model investigation," Research Report H-73-1, U.S. Army Engineer Waterways Experiment Station, Vicksburg, MS.

Long, C.E., and Ward, D.L. (1987). "Time series analysis," unpublished computer program, U.S. Army Engineer Waterways Experiment Station, Vicksburg, MS.

Stevens, J.C., Bardsley, C.E., Lane, E.W., and Straub, L.G. (1942). "Hydraulic models." Manuals on engineering practice No. 25. American Society of Civil Engineers, New York. 


\section{Appendix A \\ Photographs of Ofu Break- water 2-D Stability Tests}




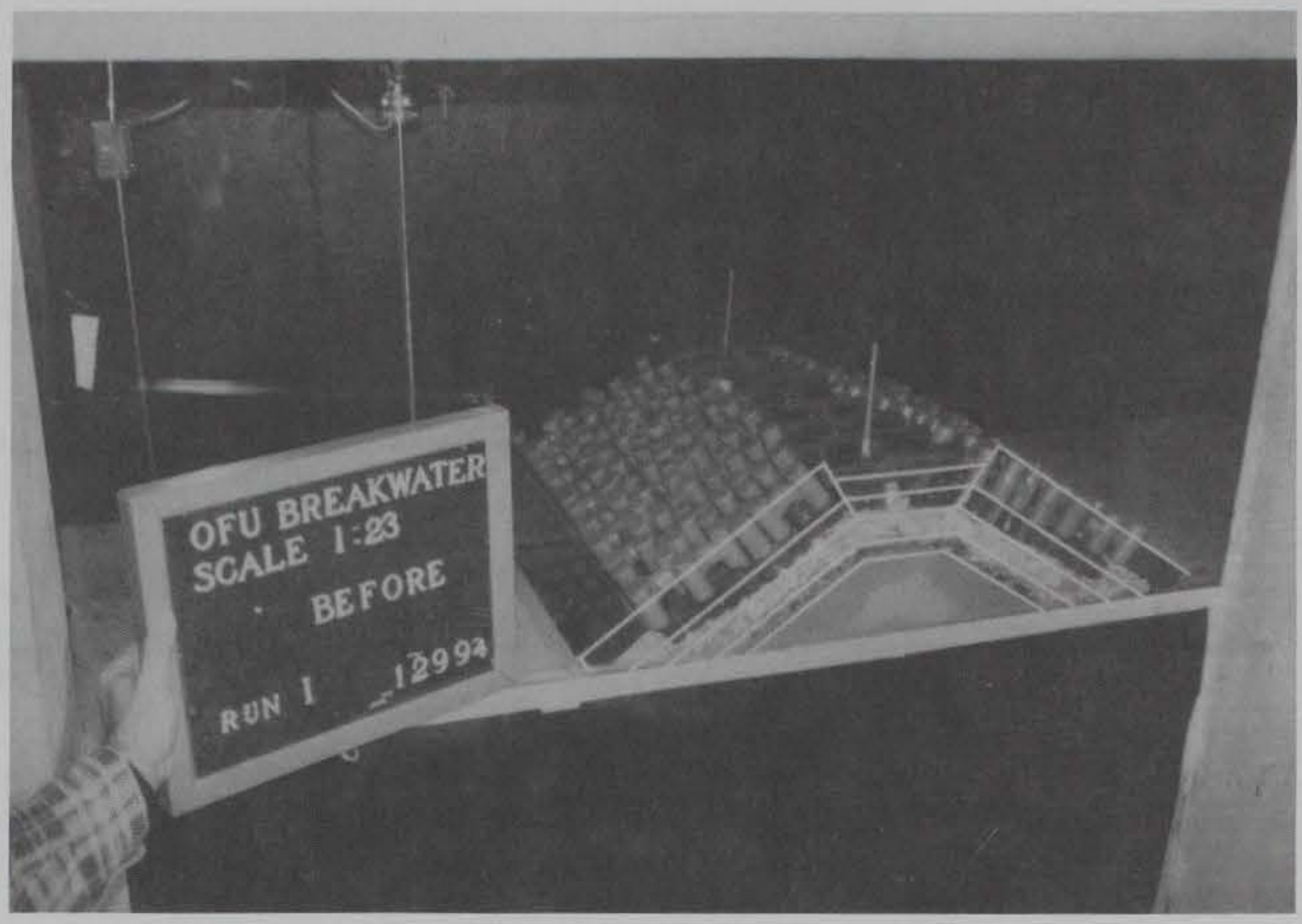

Figure A1. Model of Ofu breakwater

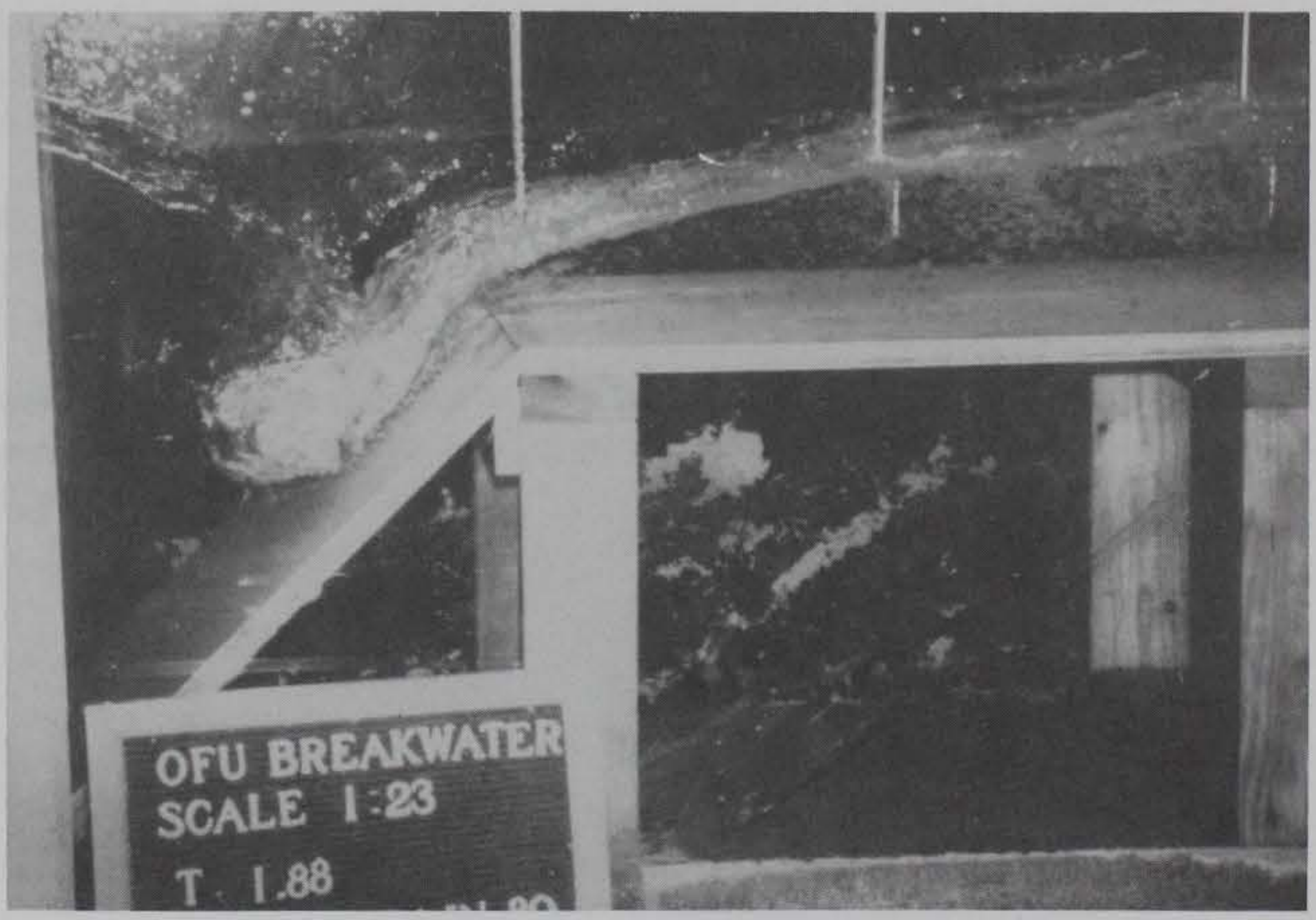

Figure A2. Trough of short-period wave $(T=9 \mathrm{sec})$ passing over reef 


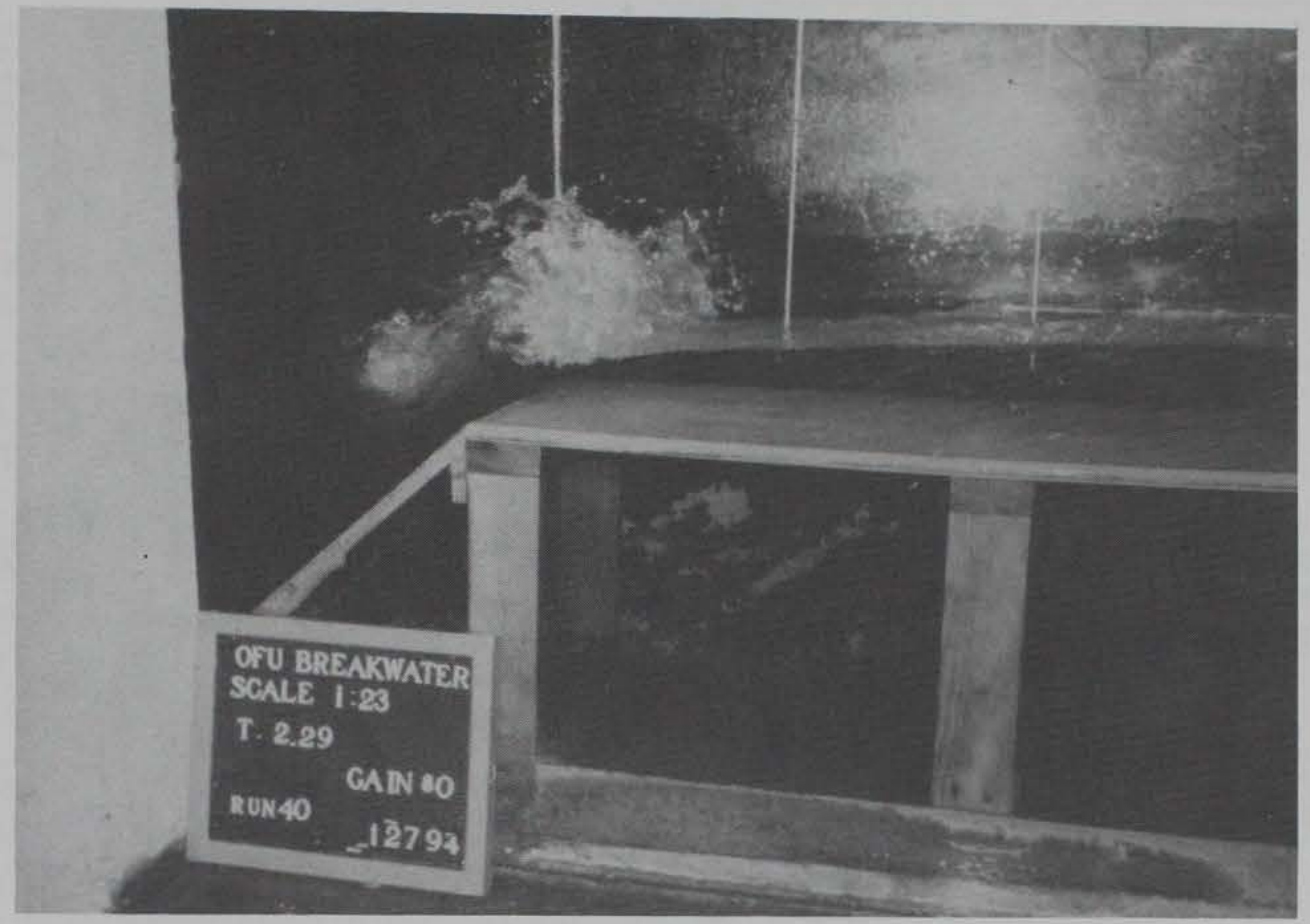

Figure A3. Short-period wave $(T=11 \mathrm{sec})$ breaking on reef

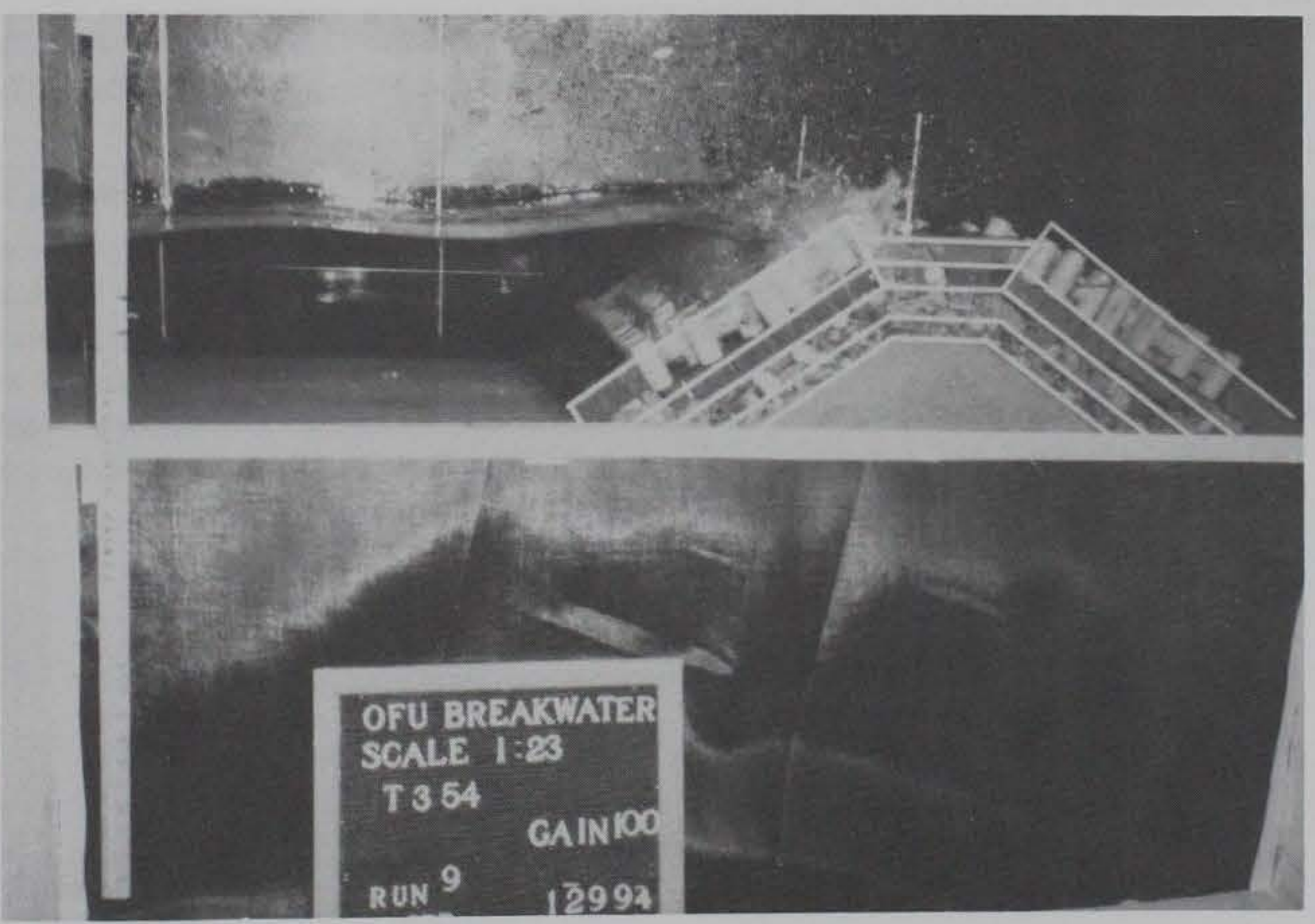

Figure A4. Wave ( $T=17 \mathrm{sec})$ breaking on structure 


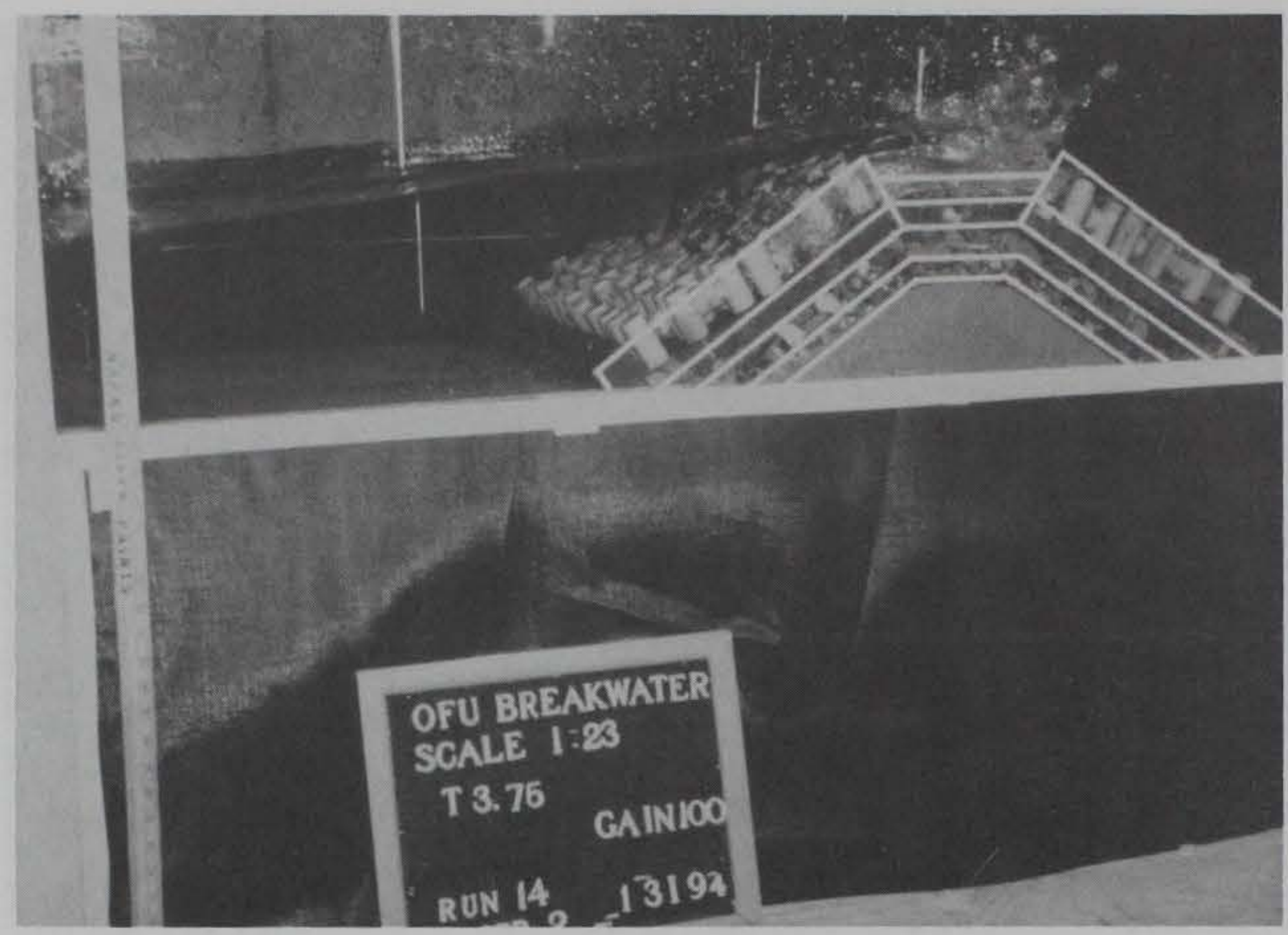

Figure A5. Wave ( $T=18 \mathrm{sec})$ breaking on structure 


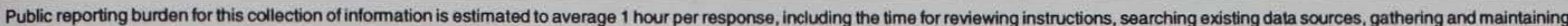

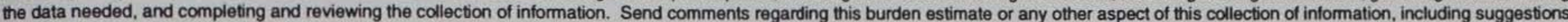

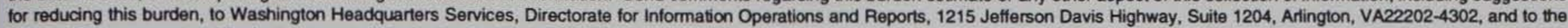
Office of Management and Budget, Paperwork Reduction Project (0704-0188), Washington, DC20503.
1. AGENCY USE ONLY (Leave blank)
2. REPORT DATE October 1995
3. REPORT TYPE AND DATES COVERED Final report

4. TITLE AND SUBTITLE

Ofu Harbor, American Samoa, Breakwater 2-D Hydraulic Stability Test

5. FUNDING NUMBERS

6. AUTHOR(S)

George F. Turk

7. PERFORMING ORGANIZATION NAME(S) AND ADDRESS(ES)

U.S. Army Engineer Waterways Experiment Station

3909 Halls Ferry Road, Vicksburg, MS 39180-6199

8. PERFORMING ORGANIZATION REPORT NUMBER

Technical Report CERC-95-16
9. SPONSORING/MONITORING AGENCY NAME(S) AND ADDRESS(ES)

U.S. Army Engineer Division, Pacific Ocean

Ft. Shafter, HI $96858-5440$
10. SPONSORING/MONITORING AGENCY REPORT NUMBER

\section{SUPPLEMENTARY NOTES}

Available from National Technical Information Service, 5285 Port Royal Road, Springfield, VA 22161.

12a. DISTRIBUTIONAVAILABILITY STATEMENT

12b. DISTRIBUTION CODE

Approved for public release; distribution is unlimited.

\section{ABSTRACT (Maximum 200 words)}

This report describes a two-dimensional physical model investigation of the Ofu breakwater, American Samoa. Two-dimensional wave tests were conducted to determine the stability of selected concrete armor units when placed on concrete revetment blocks and subjected to a design condition of a $17-\mathrm{sec}, 3.47-\mathrm{m}(11.4-\mathrm{ft})$ wave. A proposed breakwater consisted of 4.1-tonne (4.5-U.S.-ton) tribar armor units, placed on an underlayer of 1.45-tonne (1.6-U.S.-ton) 30-percent porosity blocks, secured at the crown transition with a concrete rib cap. Testing indicated that units will remain hydraulically stable for the specified design wave condition.

14. SUBJECT TERMS Concrete armor units Ofu breakwater Ofu Harbor
Porosity blocks

Two-dimensional wave tests
15. NUMBER OF PAGES 36

16. PRICE CODE

17. SECURITY CLASSIFICATION
OF REPORT
UNCLASSIFIED

NSN 7540-01-280-5500
18. SECURITY CLASSIFICATION OF THIS PAGE

UNCLASSIFIED
19. SECURITY CLASSIFICATION OF ABSTRACT
20. LIMITATION OF ABSTRACT 